\title{
Article \\ Biochar Addition Inhibits Nitrification by Shifting Community Structure of Ammonia-Oxidizing Microorganisms in Salt-Affected Irrigation-Silting Soil
}

\author{
Rong-Jiang Yao ${ }^{1}{ }^{\circledR}$, Hong-Qiang Li ${ }^{1,2}$, Jing-Song Yang ${ }^{1, *}$, Xiang-Ping Wang ${ }^{1}$, Wen-Ping Xie ${ }^{1}$ and Xing Zhang ${ }^{1}$ \\ 1 State Key Laboratory of Soil and Sustainable Agriculture, Institute of Soil Science, Chinese Academy of \\ Sciences, Nanjing 210008, China; rjyao@issas.ac.cn (R.-J.Y.); lihongqiang@issas.ac.cn (H.-Q.L.); \\ xpwang@issas.ac.cn (X.-P.W.); wpxie@issas.ac.cn (W.-P.X.); xzhang@issas.ac.cn (X.Z.) \\ 2 College of Resources and Environment, University of Chinese Academy of Sciences, Beijing 100049, China \\ * Correspondence: jsyang@issas.ac.cn; Tel.: +86-25-8688-1222
}

check for updates

Citation: Yao, R.-J.; Li, H.-Q.; Yang, J.-S.; Wang, X.-P.; Xie, W.-P.; Zhang, X. Biochar Addition Inhibits Nitrification by Shifting Community Structure of Ammonia-Oxidizing Microorganisms in Salt-Affected Irrigation-Silting Soil. Microorganisms 2022, 10, 436. https://doi.org/ 10.3390/microorganisms10020436 Academic Editor: Olli H. Tuovinen

Received: 6 February 2022 Accepted: 12 February 2022 Published: 14 February 2022

Publisher's Note: MDPI stays neutral with regard to jurisdictional claims in published maps and institutional affiliations.

Copyright: (C) 2022 by the authors. Licensee MDPI, Basel, Switzerland. This article is an open access article distributed under the terms and conditions of the Creative Commons Attribution (CC BY) license (https:// creativecommons.org/licenses/by/ $4.0 /)$.

\begin{abstract}
Biochar has been widely recognized as an effective and eco-friendly ameliorant for saline soils, but information about the mechanism of how biochar influences nitrification in salt-affected agroecosystem remains fragmented. An incubation experiment was performed on the salt-affected soil collected from a three-consecutive-year experiment at biochar application gradients of $7.5 \mathrm{t} \cdot \mathrm{ha}^{-1}$, $15 \mathrm{t} \cdot \mathrm{ha}^{-1}$ and 30.t ha ${ }^{-1}$ and under nitrogen (N) fertilization. Responses of the nitrification rate $(\mathrm{NR})$, numbers of ammonia monooxygenase $(a m o A)$ gene copies, and community structures of ammonia-oxidizing bacteria (AOB) and archaea (AOA) to biochar application were investigated. The results indicated that, under $\mathrm{N}$ fertilization, the NR and numbers of $a m o A-\mathrm{AOB}$ and $a m o A-\mathrm{AOA}$ gene copies negatively responded to biochar addition. Biochar application increased the community diversity of AOB but decreased that of AOA. Biochar addition and $\mathrm{N}$ fertilization shifted the AOB community from Nitrosospira-dominated to Nitrosospira and Nitrosomonas-dominated, and altered the AOA community from Nitrososphaera-dominated to Nitrososphaera and Nitrosopumilus-dominated. The relative abundance of Nitrosospira, Nitrosomonas and Nitrosopumilus decreased, and that of Nitrosovibrio and Nitrososphaera increased with biochar application rate. Soil SOC, $\mathrm{pH}$ and $\mathrm{NO}_{3}{ }^{-}-\mathrm{N}$ explained $87.1 \%$ of the variation in the $\mathrm{AOB}$ community, and $78.1 \%$ of the variation in the AOA community was explanatory by soil $\mathrm{pH}$ and SOC. The SOC and $\mathrm{NO}_{3}{ }^{-}-\mathrm{N}$ influenced $\mathrm{NR}$ through Nitrosovibrio, Nitrosomonas, Norank_c_environmental_samples_p_Crenarchaeota and amoA-AOB and amoA-AOA gene abundance. Therefore, biochar addition inhibited nitrification in salt-affected irrigation-silting soil by shifting the community structures of $\mathrm{AOB}$ and $\mathrm{AOA}$ and reducing the relative abundance of dominant functional ammonia-oxidizers, such as Nitrosospira, Nitrosomonas and Nitrosopumilus.
\end{abstract}

Keywords: community structure; ammonia-oxidizing microorganisms; nitrification; biochar; saltaffected soil

\section{Introduction}

Nitrogen is an indispensable nutrient element for sustaining ecosystem productivity and plays a pivotal role in closing crop yield gaps to meet ever-increasing food demands [1]. In salt-affected areas worldwide, extensively distributed saline soils, which are promising reserve land resources for compensating for the shortfall in food requirements, exert adverse impacts on crop growth and nitrogen nutrient uptake and result in nitrogen loss and environmental problems such as greenhouse gas emissions and nonpoint source pollution [2]. The migration and transformation processes of nitrogen in agricultural ecosystems are greatly affected by soil salinity and derivative obstacle factors [3]. Therefore, the amendment of soil salinization hazards is indispensable for enhancing soil productivity, improving nitrogen nutrient utilization, and minimizing environmental losses of nitrogen [4]. 
Numerous measures have been developed to amend soil salinization by physically improving soil porosity, chemically accelerating ion exchange and leaching, and biologically promoting soil biochemical function $[5,6]$. Among these methods, biochar is globally recognized as an environmentally friendly amendment owing to merits such as easy accessibility of raw materials and its harmless and pollution-free nature [7] and has been widely used in saline soil amelioration [8]. To date, many efforts have been devoted to investigating the responses of nitrogen morphological conversion, most often through microbe-mediated processes, to biochar addition in saline environments. Therefore, the effect and mechanism of biochar addition on nitrification have received increasing attention, as nitrification is closely related to mineralization, fixation, and denitrification [9]. However, recent reviews of the effect of biochar on nitrification in salt-affected soil are inconsistent and even contradictory. The biochar effect on nitrification varies owing to different soil salinity levels, ionic compositions of soluble salts, soil textures, and initial nutrient statuses [10]. Most researchers have reported a stimulating effect of biochar on nitrification, as biochar promotes soil microbial activity, nutrient availability, and biochemical function due to its high specific surface area, hydrophilicity, and adsorption capacity [11]. Some researchers have also discovered an inhibitory effect of biochar on nitrification due to surface free radicals, increasing the soil $\mathrm{pH}$, and reducing the bioavailability of $\mathrm{NH}_{4}{ }^{+}-\mathrm{N}[12,13]$.

Ammonia oxidation, catalyzed by ammonia-oxidizing bacteria (AOB) and ammoniaoxidizing archaea (AOA), is the rate-limiting step of autotrophic nitrification [14]. Previous reports have shown that $\mathrm{AOB}$ regulate ammonia oxidation in neutral and alkaline environments, whereas AOA dominate ammonia oxidation in low-pH environments [15]. In salt-affected soil, soil salinity has strong negative effects on the numbers of amoA-AOB and $a m o A-A O A$ gene copies, but the effects of biochar on the abundance of $\mathrm{AOB}$ and $\mathrm{AOA}$ in saline soil are inconsistent. The abundance of $\mathrm{AOB}$ and $\mathrm{AOA}$ decreased with biochar addition in saline-alkali soil, and AOB were more susceptible than AOA to biochar addition [16]. It was reported that biochar application significantly increased the abundance of $\mathrm{AOB}$ and $\mathrm{AOA}$, and the rate and dynamics of nitrification were closely associated with the rate of biochar application [17]. In addition to the abundance, the community structures of $\mathrm{AOB}$ and $\mathrm{AOA}$ are altered by biochar addition in salt-affected soil, and the dominant genera Nitrosospira, Nitrosomonas, Nitrosovibrio, Nitrososphaera and Nitrosopumilus are the most frequently reported taxa that were sensitive to biochar addition [18]. It was also reported that biochar addition increased the diversity and abundance of $a m o A-A O B$ gene and shifted the AOB community structure from Nitrosospira-dominated toward Nitrosomonasdominated [19]. It was in line with Shi et al. who revealed that biochar application enhanced the abundance of amoA-AOB and amoA-AOA genes, and the genera Nitrosospira (AOB) and Nitrososphaera (AOA) achieved absolute superiority [20].

In summary, the influencing mechanism of biochar application on the potential nitrification rate (PNR), abundance and community structure of ammonia-oxidizing microorganisms has attracted increasing interest. However, most of the present conclusions concerning salt-affected soils are derived from experiments conducted under certain conditions and are fragmented. Little is known about the mechanism of the functional and structural responses of nitrification to biochar addition in salt-affected irrigation-silting soil. In the present study, an aerobic incubation experiment was conducted on soils sampled from a three-consecutive-year field plot trial at different biochar application rates under $\mathrm{N}$ fertilization. The nitrification rate and the amo $A$ gene copies, diversity and community structures of $\mathrm{AOB}$ and $\mathrm{AOA}$ were measured using quantitative PCR amplification and Illumina MiSeq sequencing. The primary objectives were to: (i) investigate the responses of the nitrification rate and numbers of $a m o A-\mathrm{AOB}$ and $a m o A-\mathrm{AOA}$ gene copies to biochar at different application rates; (ii) clarify the effect of biochar addition on the diversity, community ordinations and structures of $\mathrm{AOB}$ and $\mathrm{AOA}$; and (iii) identify the causal relationships among soil properties, the numbers of $a m o A-\mathrm{AOB}$ and $a m o A-\mathrm{AOA}$ gene copies, relative abundance of dominant genera, and nitrification rate. 


\section{Materials and Methods}

\subsection{Description of Field Plot Trial}

Soil samples used in the present experiment were collected from a three-consecutiveyear field plot trial conducted in salt-affected farmland in Dengni Village $\left(40^{\circ} 49.4^{\prime} \sim 40^{\circ} 49.8^{\prime} \mathrm{N}\right.$, $106^{\circ} 54.7^{\prime} \sim 120^{\circ} 55.2^{\prime}$ E), Hanggin Rear Banner of Inner Mongolia, China. The field trial is located in the northwestern of Hetao Irrigation District (HID), which is a typical irrigated area in the upper and middle reaches of the Yellow River basin in China [21]. Details of the experimental site and field plot trial were given in [22]. Briefly, the field plot trial in a completely randomized plot design consisted of five treatments: CK (control, no N fertilization or biochar input), $\mathrm{N}$ ( $\mathrm{N}$ fertilization at $\left.225 \mathrm{~kg} \mathrm{~N} \mathrm{ha}{ }^{-1} \cdot \mathrm{yr}^{-1}\right), \mathrm{NB} 1$ ( $\mathrm{N}$ fertilization at $225 \mathrm{~kg} \mathrm{~N} \mathrm{ha}{ }^{-1} \cdot \mathrm{yr}^{-1}$, biochar rate at $\left.7.5 \mathrm{t} \mathrm{ha}^{-1}\right)$, NB2 (N fertilization at $225 \mathrm{~kg} \mathrm{~N} \mathrm{ha}{ }^{-1} \cdot \mathrm{yr}^{-1}$, biochar rate at $15 \mathrm{tha}^{-1}$ ) and NB3 ( $\mathrm{N}$ fertilization at $225 \mathrm{~kg} \mathrm{~N} \mathrm{ha}{ }^{-1} \cdot \mathrm{yr}^{-1}$, biochar rate at $30 \mathrm{tha}^{-1}$ ). Using the conventional irrigation and agronomic management practices, the sunflower (Helianthus annuus L.) variety "SH361" was planted in the field plot trial throughout the experimental period, i.e., from May 2017 to September 2019.

The biochar used in the field plot trial was produced by pyrolyzing and charring wheat straw at $400 \sim 450{ }^{\circ} \mathrm{C}$ for $4 \mathrm{~h}$ under oxygen-restricted circumstances. The basic properties of the biochar were detailed described in [23]. Biochar was added to field plots in May 2017 and manually mixed with $0-20 \mathrm{~cm}$ soil layer prior to the start of the experiment. Nitrogen fertilizer was applied to field plots in batches during the growth period of sunflower. The experiment lasted three consecutive years, and soil-biochar mixture samples at the 0-20 cm layer were obtained at the end of the experiment, i.e., after the sunflower harvest in September 2019. The fresh samples were air dried, crushed, sieved and mixed together to form one representative soil sample for each treatment. Each soil sample was subdivided into two subsamples: one was used for the lab analysis of basic soil properties, and the other was stored at $4{ }^{\circ} \mathrm{C}$ for the incubation experiment.

\subsection{Soil Microcosm Construction and Incubation}

Prior to the incubation experiment, soil microcosms were established for each treatment by adding $30 \mathrm{~g}$ of soil or a soil-biochar mixture (on an oven-dried basis) to a $250 \mathrm{~mL}$ Mason jar. All jars were moistened to $60 \%$ water-filled pore space (WFPS) using distilled water and placed in a thermostatic incubator for pre-incubation at $25 \pm 1^{\circ} \mathrm{C}$ in the dark for 3 days to revive soil microbial activity. The top of each jar was wrapped using plastic films with small holes to ventilate and prevent moisture losses. After pre-incubation, soil samples were collected as the initial soil status. Meanwhile, the soil microcosms were fertilized with $\left(\mathrm{NH}_{4}\right)_{2} \mathrm{SO}_{4}$ solution at a rate of $200 \mathrm{mg} \mathrm{N} \mathrm{kg}^{-1}$ dry weight soil and moistened to keep the soil moisture at $65 \%$ WFPS. Using the weighing method, deionized water was added to each microcosm to maintain constant moisture content during the incubation. The incubation lasted 35 days, and soil samples were collected from the microcosms on the $1 \mathrm{st}, 3 \mathrm{rd}, 7 \mathrm{th}, 10 \mathrm{th}, 15 \mathrm{th}, 25 \mathrm{th}$ and 35th days. Each treatment had 24 replicate microcosms and triplicate microcosms were used for each sampling, and 24 replicas were used up after eight soil samplings (including soil sampling after pre-incubation). The collected soil samples were sieved through a mesh size of $2 \mathrm{~mm}$ and subdivided into two subsamples: one was stored at $4{ }^{\circ} \mathrm{C}$ for soil chemical analysis, and the other was stored at $-80{ }^{\circ} \mathrm{C}$ for soil microbiological analysis.

\subsection{Laboratory Analysis}

For the soil samples used in microcosm construction and incubation, the analyzed physio-chemical properties consisted of soil salinity $\left(\mathrm{EC}_{1: 5}\right), \mathrm{pH}$, cation exchange capacity (CEC), soil organic carbon (SOC), total nitrogen (TN), $\mathrm{NH}_{4}{ }^{+}-\mathrm{N}$ and $\mathrm{NO}_{3}{ }^{-}-\mathrm{N}$ contents, and available potassium (AP). The $\mathrm{EC}_{1: 5}$ and $\mathrm{pH}$ were measured on 1:5 soil:water $(w / v)$ suspensions. The CEC was measured using the ammonium acetate extraction method. The SOC and TN were analyzed by wet digestion with $\mathrm{H}_{2} \mathrm{SO}_{4}-\mathrm{K}_{2} \mathrm{Cr}_{2} \mathrm{O}_{7}$ and semimicro Kjeldahl digestion. Soil $\mathrm{NH}_{4}{ }^{+}-\mathrm{N}$ and $\mathrm{NO}_{3}{ }^{-}-\mathrm{N}$ contents were determined on a 1:5 soil: $\mathrm{KCl}(2 \mathrm{M})$ 
extract using ultraviolet spectrophotometry. The AP (Olsen P) was analyzed by the sodium bicarbonate extraction and colorimetric analysis. Detailed analytical procedures for the above soil attributes referred to [24]. The measured basic soil properties for all treatments are shown in Table 1.

Table 1. Basic soil properties for all the treatments (mean \pm standard deviation), and the one-way ANOVA results with the least significant difference (LSD).

\begin{tabular}{|c|c|c|c|c|c|c|c|c|}
\hline Treatments & $\begin{array}{c}E_{1: 5} \\
\left(\mathrm{dS} \cdot \mathrm{m}^{-1}\right)\end{array}$ & $\mathbf{H}$ & $\begin{array}{c}\text { CEC } \\
\left(\mathrm{cmol}^{\circ} \mathrm{kg}^{-1}\right)\end{array}$ & $\underset{\left(\mathrm{g} \cdot \mathrm{kg}^{-1}\right)}{\mathrm{SOC}}$ & $\begin{array}{c}\mathrm{TN} \\
\left(\mathrm{g} \cdot \mathrm{kg}^{-1}\right)\end{array}$ & $\begin{array}{c}\mathrm{NH}_{4}^{+}-\mathrm{N} \\
\left(\mathrm{mg} \cdot \mathrm{kg}^{-1}\right)\end{array}$ & $\begin{array}{c}\mathrm{NO}_{3}^{-}-\mathrm{N} \\
\left(\mathrm{mg} \cdot \mathrm{kg}^{-1}\right)\end{array}$ & $\begin{array}{c}\mathrm{AP} \\
\left(\mathrm{mg} \cdot \mathrm{kg}^{-1}\right)\end{array}$ \\
\hline CK & a & c & $\mathrm{C}$ & $\begin{array}{c}11.01 \perp 0.21 \\
\mathrm{c}\end{array}$ & $\begin{array}{c}0.60 \pm 0.08 \\
b\end{array}$ & $\begin{array}{c}14.98 \pm 1.64 \\
c\end{array}$ & $\begin{array}{c}35.72 \pm 2.89 \\
c\end{array}$ & $\begin{array}{c}21.67 \pm 2.67 \\
b c\end{array}$ \\
\hline $\mathrm{N}$ & $\begin{array}{c}1.42 \pm 0.20 \\
\mathrm{a}\end{array}$ & $\begin{array}{c}8.18 \pm 0.03 \\
c\end{array}$ & $\begin{array}{c}14.55 \pm 0.43 \\
\mathrm{bc}\end{array}$ & $\begin{array}{c}13.43 \pm 0.63 \\
b\end{array}$ & $\begin{array}{c}0.69 \pm 0.14 \\
\mathrm{ab}\end{array}$ & $\begin{array}{c}20.53 \pm 1.21 \\
b\end{array}$ & $\begin{array}{c}51.29 \pm 3.19 \\
a b\end{array}$ & $\begin{array}{c}19.28 \pm 1.91 \\
\mathrm{C}\end{array}$ \\
\hline NB1 & $\begin{array}{c}1.31 \pm 0.16 \\
\mathrm{a}\end{array}$ & $\begin{array}{c}8.32 \pm 0.07 \\
b\end{array}$ & $\begin{array}{c}15.12 \pm 0.49 \\
b\end{array}$ & $\begin{array}{c}13.82 \pm 0.95 \\
\mathrm{ab}\end{array}$ & $\begin{array}{c}0.72 \pm 0.15 \\
a\end{array}$ & $\begin{array}{c}22.27 \pm 1.27 \\
\mathrm{ab}\end{array}$ & $\begin{array}{c}50.11 \pm 3.20 \\
\mathrm{ab}\end{array}$ & $\begin{array}{c}23.10 \pm 2.41 \\
b\end{array}$ \\
\hline NB2 & $\begin{array}{c}1.24 \pm 0.10 \\
\mathrm{a}\end{array}$ & $\begin{array}{c}8.40 \pm 0.03 \\
\mathrm{a}\end{array}$ & $\begin{array}{c}17.45 \pm 1.08 \\
\mathrm{a}\end{array}$ & $\begin{array}{c}14.83 \pm 0.27 \\
\mathrm{a}\end{array}$ & $\begin{array}{c}0.69 \pm 0.07 \\
\mathrm{ab}\end{array}$ & $\begin{array}{c}20.65 \pm 2.56 \\
b\end{array}$ & $\begin{array}{c}53.51 \pm 2.17 \\
\mathrm{a}\end{array}$ & $\begin{array}{c}26.49 \pm 1.55 \\
a b\end{array}$ \\
\hline NB3 & $\begin{array}{c}1.21 \pm 0.02 \\
\mathrm{a}\end{array}$ & $\begin{array}{c}8.41 \pm 0.02 \\
\mathrm{a}\end{array}$ & $\begin{array}{c}17.78 \pm 0.23 \\
\mathrm{a}\end{array}$ & $\begin{array}{c}14.43 \pm 0.64 \\
\mathrm{a}\end{array}$ & $\begin{array}{c}0.67 \pm 0.16 \\
\mathrm{ab}\end{array}$ & $\begin{array}{c}24.40 \pm 2.11 \\
a\end{array}$ & $\begin{array}{c}46.43 \pm 1.58 \\
\mathrm{ab}\end{array}$ & $\begin{array}{c}28.38 \pm 3.50 \\
a\end{array}$ \\
\hline
\end{tabular}

$\mathrm{EC}_{1: 5}$ : electrical conductivity of 1:5 soil:water extract; CEC: cation exchange capacity; SOC: soil organic carbon; TN total nitrogen; $\mathrm{NH}_{4}{ }^{+}-\mathrm{N}$ : ammonium nitrogen content; $\mathrm{NO}_{3}{ }^{-}-\mathrm{N}$ : nitrate nitrogen content; AP: available potassium. Different lowercase letters indicate significance at $p \leq 0.05$.

For the incubation soil samples, concentrations of $\mathrm{NH}_{4}{ }^{+}-\mathrm{N}$ and $\mathrm{NO}_{3}{ }^{-}-\mathrm{N}$ were analyzed for all the samples collected on different dates, and the soil samples collected on the 10 th day of incubation were selected for analyzing the ammonia monooxygenase (subunit $\mathrm{A}, a m o A)$ gene copies and community structures of ammonia oxidizing bacteria (AOB) and ammonia-oxidizing archaea (AOA). This was done considering the dynamic characteristics of nitrification in salt-affected soils, and the differences in nitrification rate and amo $A$ gene number were significant among different treatments on the 10th day.

\subsection{Soil DNA Extraction, Quantitative PCR (qPCR) Amplification of amoA Genes}

Soil total genomic DNA was extracted using the E.Z.N.A. ${ }^{\circledR}$ Soil DNA Kit (Omega BioTek, Norcross, GA, USA) according to the procedure suggested by [25]. Using a NanoDrop ${ }^{\circledR}$ ND-2000c UV-Vis spectrophotometer (NanoDrop Technologies, Wilmington, DE, USA), the content and purity of the extracted genomic DNA was quantified using agarose gel electrophoresis (AGE) at 1\% content. Quantitative PCR ( $q$ PCR) was performed with duplicate sets of extracted DNA in an Mx3005P instrument (Stratagene, Santa Clara, CA, USA) with a Brilliant II SYBR Green QPCR Master Mix (Stratagene, La Jolla, CA, USA). The amplification primers, sequences and reaction conditions of $q P C R$ for amoA-AOB and amoA-AOA genes are shown in Table S1. Detailed procedures of $q \mathrm{PCR}$ reaction, standard DNA preparation and count of gene copies for AOB and AOA were given in [22,26]. The qPCR amplification efficiencies were $98.32 \%$ and $97.55 \%$ for AOB and AOA, respectively.

\subsection{Illumina MiSeq Sequencing and Phylogenetic Analysis}

The above obtained PCR products were checked using $2 \%$ agarose gel electrophoresis and purified using an AxyPrep DNA gel extraction kit (Axygen, Union City, CA, USA) to remove any unspecified products. Then, the PCR products were eluted with Tris-HCl buffer and checked using $2 \%$ agarose gel electrophoresis again. Purified amplicons were mixed in equimolar amounts and sequenced on an Illumina MiSeq Benchtop Sequencer (Illumina, San Diego, CA, USA). After sequencing, the sequences were checked and optimized using the Trimmomatic software. Operational taxonomic units (OTUs) were defined according to $97 \%$ similarity using USEARCH v7 [27]. The representative sequences of the main OTUs were selected for alignment in the NCBI database to find the homologs and the closest sequences. The detailed procedure of bioinformatic analysis was described in [28]. 


\subsection{Statistical Analysis}

The nitrification rate (NR) was calculated according to the formulae proposed by [29]. The diversity and abundance-based richness within the community was evaluated using indices including observed OTUs, Chao1, ACE, Shannon and Simpson [30]. Based on SPSS Statistics 17.0 (IBM Company, Armonk, NY, USA), one-way analysis of variance (ANOVA) was used to compare the basic soil properties, nitrification rate, numbers of amoA-AOB and amoA-AOA gene copies, and community richness and diversity among different treatments. The relative abundance of dominant taxa at the order and genus levels was also compared using one-way ANOVA for the AOB and AOA, respectively. CANOCO 5.0 (Microcomputer Power, Ithaca, NY, USA) was used to perform principal coordinate analysis (PCoA) and redundancy analysis (RDA) to reveal the community ordinations and environmental relationships. Using AMOS 23.0 (IBM, Meadville, PA, USA), structural equation modeling (SEM) was conducted to identify the causal effects of soil microhabitat traits, relative abundance of dominant genera of $\mathrm{AOB}$ and $\mathrm{AOA}$, and the numbers of amo $A-\mathrm{AOB}$ and $a m o A-\mathrm{AOA}$ gene copies on nitrification rates under biochar addition. The criteria for assessing the performance of model fitting referred to [31].

\section{Results}

\subsection{Nitrification Rate and amoA Gene Number}

The nitrification rate (NR) within the 7th and 10th day of incubation and the numbers of amoA-AOB and amoA-AOA gene copies are given in Table 2. The average net NR values were $28.15,27.64,21.8,15.74$ and $11.67 \mathrm{mg} \cdot \mathrm{kg}^{-1} \cdot \mathrm{d}^{-1}$ for the CK, N, NB1, NB2 and NB3 treatments, respectively. One-way ANOVA results showed that the NR value under the $\mathrm{CK}$ treatment was not different from that under the $\mathrm{N}$ treatment, and the NR values under the CK and N treatments were significantly higher than those under the NB2 and NB3 treatments. Overall, biochar addition resulted in the decrease of NR and the treatment with the highest amount of biochar $\left(30 \mathrm{t} \cdot \mathrm{ha}^{-1}\right)$ had the lowest NR value. Actually, the NR varied temporally during the autotrophic nitrification process (Supplementary Figure S1), and the variation in NR could be ascribed to the dynamics of community structure and function of ammonia-oxidizing microorganisms, bioavailability of substrate, and soil microhabitat traits [23].

Table 2. Nitrification rate and the numbers of amoA-AOB and amoA-AOA gene copies for all the treatments, plus the one-way ANOVA results with the least significant difference (LSD).

\begin{tabular}{cccc}
\hline Treatments & $\begin{array}{c}\text { Nitrification Rate (NR) } \\
\left(\mathbf{m g} \cdot \mathbf{k g}^{-\mathbf{1}} \cdot \mathbf{d}^{-\mathbf{1}} \mathbf{)}\right.\end{array}$ & $\begin{array}{c}\text { amoA-AOB Gene Copies } \\
\left(\times \mathbf{1 0}^{\mathbf{7}} \mathbf{g}^{-\mathbf{1}} \text { Soil) }\right.\end{array}$ & $\begin{array}{c}\text { amoA-AOA Gene Copies } \\
\left(\times \mathbf{1 0}^{\mathbf{6}} \mathbf{g}^{-\mathbf{1}} \mathbf{S o i l )}\right)\end{array}$ \\
\hline CK & $28.15 \pm 6.13 \mathrm{a}$ & $8.21 \pm 0.54 \mathrm{a}$ & $3.71 \pm 0.49 \mathrm{a}$ \\
N & $27.64 \pm 5.72 \mathrm{a}$ & $4.61 \pm 0.64 \mathrm{~b}$ & $2.12 \pm 0.20 \mathrm{~b}$ \\
NB1 & $21.80 \pm 4.01 \mathrm{ab}$ & $3.52 \pm 0.63 \mathrm{bc}$ & $1.84 \pm 0.36 \mathrm{~b}$ \\
NB2 & $15.74 \pm 4.42 \mathrm{~b}$ & $2.97 \pm 0.81 \mathrm{c}$ & $0.96 \pm 0.05 \mathrm{c}$ \\
\hline
\end{tabular}

Different lower case letters indicate significance at $p \leq 0.05$.

The measured average number of $a m o A-A O B$ gene copies was $8.21 \pm 0.54,4.61 \pm 0.64$ $3.52 \pm 0.63,2.97 \pm 0.81$ and $2.50 \pm 0.43 \times 10^{7} \mathrm{~g}^{-1}$ soil under the CK, N, NB1, NB2, and NB3 treatments, respectively (Table 2), whereas the value of $a m o A$-AOA was $3.71 \pm 0.49$, $2.12 \pm 0.20,1.83 \pm 0.36,0.96 \pm 0.15$, and $0.71 \pm 0.10 \times 10^{6} \mathrm{~g}^{-1}$ soil, respectively. The amoA$\mathrm{AOB}$ gene copies outnumbered amoA-AOA gene copies for all the treatment, indicating that amoA-AOB was predominant in terms of $a m o A$ gene abundance. Following the $\mathrm{N}$ and NB1 treatments, the $\mathrm{CK}$ treatment had the highest number of amo $A-\mathrm{AOB}$ gene copies among all the treatments, and the amoA-AOB gene copies under the $\mathrm{N}$ treatment were significantly higher than those under the NB2 and NB3 treatments. This was also observed for the amoA-AOA gene copies, i.e., the NB2 and NB3 treatments had the lowest numbers 
of amoA-AOA gene copies. Overall, the abundance of both amoA-AOB and amoA-AOA genes was negatively responsive to biochar addition.

\subsection{Richness and Diversity of $A O B$ and $A O A$ Communities}

The diversity indices of $\mathrm{AOB}$ and AOA calculated from 16S rRNA gene amplicon sequencing are shown in Table 3. The $\mathrm{N}$ treatment increased the OTUs of AOB by $44.78 \%$ in comparison with the CK treatment. Compared with the N treatment, the NB1, NB2 and NB3 treatments decreased the OTUs of AOB by 3.09\%, 5.16\% and $9.28 \%$, respectively. A decreasing trend was also observed for AOA under biochar addition. The Chao1 representing the community richness varied among different treatments and between $\mathrm{AOB}$ and AOA. $N$ fertilization and biochar addition significantly increased the Chao1 index of $A O B$, and the NB3 treatment had the highest Chao1 index of 33.67. Nevertheless, no obvious difference was observed for the Chao1 index of AOA. The average ratios of OTUs/Chao1 were $95.42 \pm 6.92 \%$ and $90.00 \pm 6.37 \%$ for $\mathrm{AOB}$ and $\mathrm{AOA}$, implying that the sequencing efforts for $\mathrm{AOB}$ were more exhaustive than those for AOA. Shannon and Simpson, the community diversity indices, showed clear responses to biochar addition for AOB. In comparison with the N treatment, NB1, NB2 and NB3 treatments increased the Shannon index but decreased the Simpson index of AOB. However, the Shannon and Simpson indices of AOA exhibited opposite responses to biochar addition. The coverage index was not responsive to $\mathrm{N}$ fertilization or biochar addition for either $\mathrm{AOB}$ or AOA.

Table 3. Richness and diversity indexes of AOB and AOA, plus the statistical comparison of community indexes among all treatments using the one-way ANOVA with the least significant difference (LSD).

\begin{tabular}{|c|c|c|c|c|c|c|c|c|c|c|}
\hline \multirow[b]{2}{*}{ Treatment } & \multicolumn{5}{|c|}{ AOB } & \multicolumn{5}{|c|}{ AOA } \\
\hline & OTUs & Chao1 & Shannon & Simpson & $\begin{array}{c}\text { Coverage } \\
(\%)\end{array}$ & OTUs & Chao1 & Shannon & Simpson & $\begin{array}{c}\text { Coverage } \\
(\%)\end{array}$ \\
\hline CK & $\begin{array}{c}22.33 \pm 1.53 \\
c\end{array}$ & $\begin{array}{c}23.83 \pm 2.75 \\
b\end{array}$ & $\begin{array}{c}1.93 \pm 0.11 \\
c\end{array}$ & $\begin{array}{c}0.18 \pm 0.04 \\
\mathrm{a}\end{array}$ & $\begin{array}{c}99.97 \pm 0.01 \\
\text { a }\end{array}$ & $\begin{array}{c}30.33 \pm 4.04 \\
\text { c }\end{array}$ & $\begin{array}{c}34.22 \pm 4.83 \\
\mathrm{a}\end{array}$ & $\begin{array}{c}1.28 \pm 0.04 \\
\mathrm{~d}\end{array}$ & $\begin{array}{c}0.40 \pm 0.01 \\
\mathrm{a}\end{array}$ & $\begin{array}{c}99.95 \pm 0.02 \\
\text { a }\end{array}$ \\
\hline $\mathrm{N}$ & $\begin{array}{c}32.33 \pm 2.08 \\
\mathrm{a}\end{array}$ & $\begin{array}{c}33.33 \pm 0.58 \\
\mathrm{a}\end{array}$ & $\begin{array}{c}2.14 \pm 0.06 \\
b\end{array}$ & $\begin{array}{c}0.16 \pm 0.01 \\
a\end{array}$ & $\begin{array}{c}99.98 \pm 0.02 \\
\mathrm{a}\end{array}$ & $\begin{array}{c}38.33 \pm 2.08 \\
\mathrm{a}\end{array}$ & $\begin{array}{c}41.00 \pm 4.00 \\
\mathrm{a}\end{array}$ & $\begin{array}{c}2.15 \pm 0.07 \\
\mathrm{a}\end{array}$ & $\begin{array}{c}0.17 \pm 0.02 \\
\mathrm{~d}\end{array}$ & $\begin{array}{c}99.97 \pm 0.01 \\
\mathrm{a}\end{array}$ \\
\hline N B1 & $\begin{array}{c}31.33 \pm 2.89 \\
\mathrm{ab}\end{array}$ & $\begin{array}{c}31.79 \pm 3.29 \\
\mathrm{a}\end{array}$ & $2.11 \pm 0.10$ & $\begin{array}{c}0.17 \pm 0.02 \\
\mathrm{a}\end{array}$ & $\begin{array}{c}99.99 \pm 0.02 \\
a\end{array}$ & $\begin{array}{c}36.33 \pm 3.21 \\
\mathrm{ab}\end{array}$ & $\begin{array}{c}40.67 \pm 4.30 \\
\mathrm{a}\end{array}$ & $\begin{array}{c}1.76 \pm 0.07 \\
\mathrm{c}\end{array}$ & $\begin{array}{c}0.26 \pm 0.01 \\
b\end{array}$ & $\begin{array}{c}99.96 \pm 0.02 \\
\mathrm{a}\end{array}$ \\
\hline N B2 & $\begin{array}{c}30.67 \pm 2.52 \\
\mathrm{ab}\end{array}$ & $\begin{array}{c}31.00 \pm 2.78 \\
\mathrm{a}\end{array}$ & $\begin{array}{c}2.28 \pm 0.10 \\
b\end{array}$ & $\begin{array}{c}0.20 \pm 0.03 \\
\mathrm{a}\end{array}$ & $\begin{array}{c}99.99 \pm 0.01 \\
\mathrm{a}\end{array}$ & $\begin{array}{c}35.33 \pm 3.22 \\
\mathrm{ab}\end{array}$ & $\begin{array}{c}40.83 \pm 10.56 \\
a\end{array}$ & $\begin{array}{c}1.92 \pm 0.06 \\
b\end{array}$ & $\begin{array}{c}0.21 \pm 0.01 \\
\mathrm{c}\end{array}$ & $\begin{array}{c}99.96 \pm 0.02 \\
a\end{array}$ \\
\hline N B3 & $\begin{array}{c}29.33 \pm 0.58 \\
b\end{array}$ & $\begin{array}{c}33.67 \pm 5.03 \\
a\end{array}$ & $\begin{array}{c}2.47 \pm 0.10 \\
\mathrm{a}\end{array}$ & $\begin{array}{c}0.11 \pm 0.01 \\
\mathrm{~b}\end{array}$ & $\begin{array}{c}99.97 \pm 0.03 \\
\mathrm{a}\end{array}$ & $\begin{array}{c}35.00 \pm 1.00 \\
b\end{array}$ & $\begin{array}{c}39.28 \pm 1.84 \\
\mathrm{a}\end{array}$ & $\begin{array}{c}1.98 \pm 0.04 \\
b\end{array}$ & $\begin{array}{c}0.20 \pm 0.01 \\
c\end{array}$ & $\begin{array}{c}99.95 \pm 0.02 \\
a\end{array}$ \\
\hline
\end{tabular}

Different lowercase letters indicate a significant difference at $p<0.05$.

\subsection{Structural Characteristics of $A O B$ and $A O A$ Communities}

Table 4 shows the relative abundance of the dominant taxa at the order level. For AOB, the community composition at the order rank was affiliated with three dominant orders: $\mathrm{Ni}$ trosomonadales, Unclassified_k_norank_d_Bacteria, and Norank_p_ammonia_oxidizing_bacteria ensemble. Nitrosomonadales accounted for $95.44 \%$ of the total AOB community under the CK treatment, whereas the percentage declined to $81.59 \%, 73.26 \%, 63.08 \%$ and $58.87 \%$ under the N, NB1, NB2 and NB3 treatments, respectively. The relative abundance of unclassified_k_norank_d_Bacteria and Norank_p_ammonia_oxidizing_bacteria_ensemble increased with $\mathrm{N}$ fertilization and biochar addition. For AOA, the dominant taxa were Nitrososphaerales, Nitrosopumilales, Norank_c_environmental_samples_p_Crenarchaeota and Unclassified_k_norank _d_Archaea (Table 4). The relative abundance of Nitrososphaerales was $37.95 \%$ under the CK treatment, whereas the percentage increased to $43.15 \%, 58.76 \%, 60.23 \%$ and $51.02 \%$ under the N, NB1, NB2 and NB3 treatments, respectively. This ascending trend was also observed for Unclassified_k_norank_d_Archaea. Nitrosopumilales was negligible under the CK treatment, and $\mathrm{N}$ fertilization increased the percentage of Nitrosopumilales to $29.37 \%$, but biochar addition decreased its relative abundance under $\mathrm{N}$ fertilization. Biochar addition also 
exerted a negative influence on the relative abundance of Norank_c_environmental_samples _p_Crenarchaeota.

Table 4. Relative abundance (\%) of predominant taxa for AOB and AOA at the order level across all the treatments.

\begin{tabular}{|c|c|c|c|c|c|c|}
\hline & \multirow{2}{*}{ Taxa } & \multicolumn{5}{|c|}{ Treatment } \\
\hline & & CK & $\mathbf{N}$ & NB1 & NB2 & NB3 \\
\hline \multirow{3}{*}{$\mathrm{AOB}$} & Nitrosomonadales & $95.44 \pm 1.33 \mathrm{a}$ & $81.59 \pm 0.82 \mathrm{ab}$ & $73.26 \pm 9.68 \mathrm{bc}$ & $63.08 \pm 16.96 c$ & $58.87 \pm 3.45 c$ \\
\hline & Unclassified_k_norank_d_Bacteria & $1.07 \pm 1.04 \mathrm{c}$ & $16.35 \pm 0.87 \mathrm{~b}$ & $23.27 \pm 8.83 \mathrm{ab}$ & $30.94 \pm 11.51 \mathrm{a}$ & $31.10 \pm 3.16 \mathrm{a}$ \\
\hline & $\begin{array}{c}\text { Norank_p_ammonia_oxidising } \\
\text { _bacteria_ensemble }\end{array}$ & $3.32 \pm 1.92 b$ & $1.42 \pm 0.31 c$ & $2.97 \pm 0.52 b$ & $5.40 \pm 2.39 \mathrm{ab}$ & $9.90 \pm 1.62 \mathrm{a}$ \\
\hline \multirow{4}{*}{$\mathrm{AOA}$} & Nitrososphaerales & $37.95 \pm 1.47 b$ & $43.15 \pm 10.45 b$ & $58.76 \pm 11.75 \mathrm{a}$ & $60.23 \pm 7.82 \mathrm{a}$ & $51.02 \pm 4.17 \mathrm{ab}$ \\
\hline & Nitrosopumilales & - & $29.37 \pm 6.56 \mathrm{a}$ & $26.79 \pm 14.00 \mathrm{ab}$ & $14.41 \pm 11.43 \mathrm{ab}$ & $12.90 \pm 6.85 b$ \\
\hline & $\begin{array}{c}\text { Norank_c_environmental_samples } \\
\text { p_Crenarchaeota }\end{array}$ & $57.63 \pm 1.00 \mathrm{a}$ & $12.10 \pm 3.16 b$ & $2.45 \pm 0.80 \mathrm{~d}$ & $3.85 \pm 1.65 \mathrm{~d}$ & $7.84 \pm 1.54 \mathrm{c}$ \\
\hline & Unclassified_k_norank_d_Archaea & $4.24 \pm 0.55 \mathrm{c}$ & $14.39 \pm 2.05 \mathrm{~b}$ & $11.78 \pm 1.67 \mathrm{bc}$ & $20.87 \pm 11.30 \mathrm{ab}$ & $27.65 \pm 6.20 \mathrm{a}$ \\
\hline
\end{tabular}

Different letters indicate significant differences among different treatments for each taxonomic order based on least significant difference $(p \leq 0.05)$.

Figure 1a presents the relative abundance of the AOB community at the genus level. The most frequent genera (average relative abundance $\geq 5 \%$ ) consisted of $\mathrm{Ni}$ trosospira (47.17 $\pm 24.97 \%)$, Nitrosomonas (16.36 $\pm 10.07 \%)$, Unclassified_o_Nitrosomonadales $(9.73 \pm 6.01 \%)$ and Unclassified_k_norank_d_Bacteria $(20.49 \pm 12.85 \%)$. Genera Norank p_ammonia_oxidizing_bacteria_ensemble $(4.60 \pm 4.38 \%)$ and Nitrosovibrio $(1.09 \pm 1.16 \%)$ belonged to a second group with a lower but still important percentage $(1 \% \leq$ average relative abundance $<5 \%$ ). $\mathrm{N}$ fertilization significantly decreased the relative abundance of Nitrosospira but increased that of Nitrosomonas and Unclassified_k_norank_d_Bacteria. Furthermore, biochar addition increased the relative abundance of Nitrosovibrio, Unclassified_k_norank_d_Bacteria and Norank_p_ammonia_oxidizing_bacteria_ensemble, but decreased that of Nitrosospira under $\mathrm{N}$ fertilization. Genera Nitrosomonas and Unclassified_o_Nitrosomonadales showed no distinct response to biochar addition.
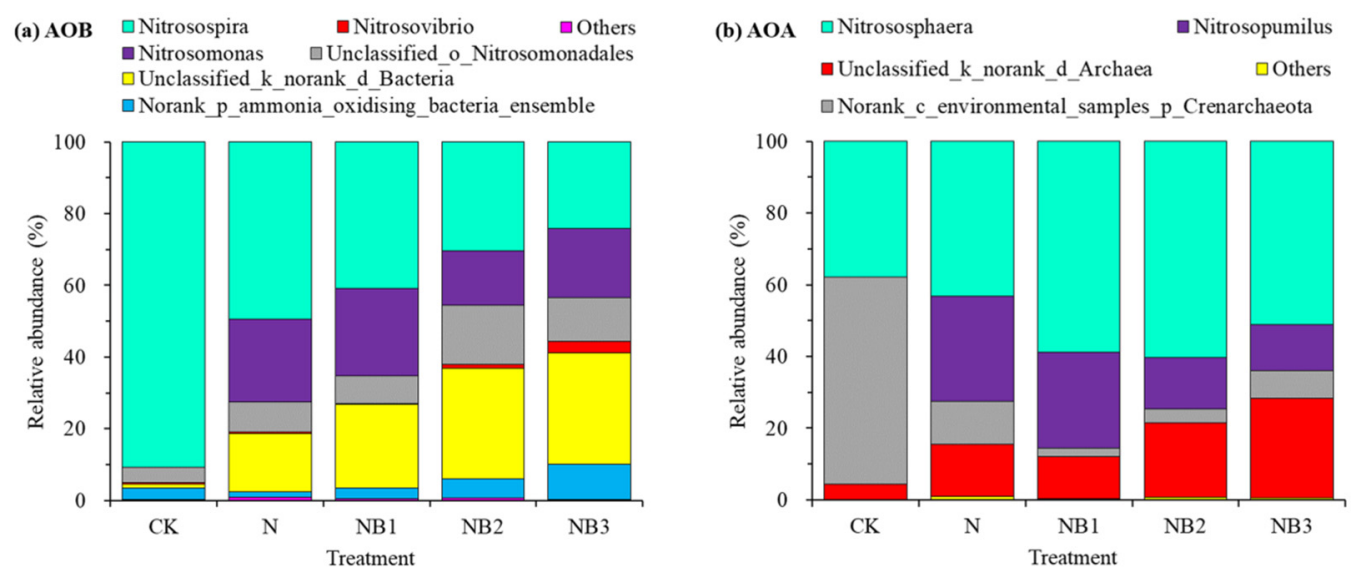

Figure 1. Relative abundance of AOB (a) and AOA (b) community structures at the genus level.

The relative abundance of the AOA community at the genus level is shown in Figure $1 \mathrm{~b}$. The predominant taxa were Nitrososphaera $(50.22 \pm 11.27 \%)$, Norank_c_environmental_samples _p_Crenarchaeota $(16.77 \pm 21.49 \%)$, Nitrosopumilus $(16.69 \pm 13.88 \%)$ and Unclassified_k _norank_d_Archaea $(15.78 \pm 9.64 \%)$. The genus Nitrosopumilus was barely observed under the $\mathrm{CK}$ treatment. The $\mathrm{N}$ fertilization significantly enhanced the percentage of Nitrosopumilus and Unclassified_k_norank_d_Archaea, and decreased that of Norank_c_environmental_samples _p_Crenarchaeota. The further application of biochar, by contrast, decreased the relative abundance of Nitrosopumilus and Norank_c_environmental_samples_p_Crenarchaeota, whereas 
increased that of Nitrososphaera and Unclassified_k_norank_d_Archaea. Figure 2 presents the $\mathrm{AOB}$ and AOA community heatmap showing the frequency distribution of the dominant genera as well as the cluster structure.
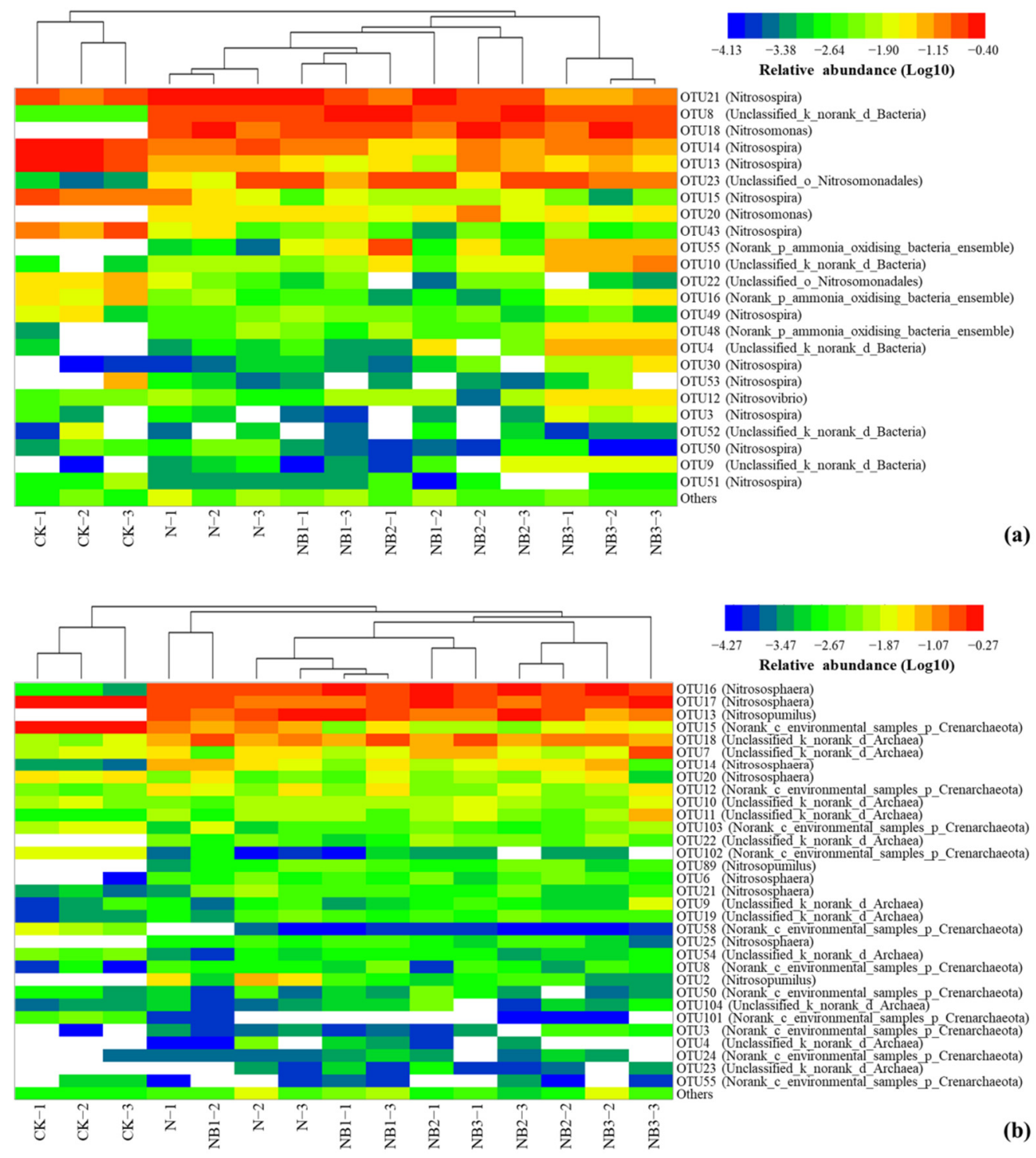

Figure 2. Heat maps showing taxa frequency distribution of OTUs for AOB (a) and AOA (b) at the genus level, plus the cluster structure across all the treatments.

\section{4. $A O B$ and $A O A$ Community Ordinations}

Principal coordinates analysis (PCoA) was used to evaluate the dissimilarity of the AOA and AOB communities. The obtained unconstrained ordination of the AOB and AOA communities and basic soil properties demonstrated that all treatments were clearly separated according to management practices (Figure 3). The first two PCs explained $57.88 \%$ of the variability in the AOB community and $73.60 \%$ of the variability in the AOA community. For AOB, the first principal component (PC1), which explained 46.72\% of the variation in the data, separated the communities in the $\mathrm{CK}$ treatment from those in the other treatments. The second principal component (PC2) explained 11.16\% of the data variance and separated the communities in the NB1, NB2 and NB3 treatments from those in the $\mathrm{N}$ treatment (Figure 3a). Likewise, AOA communities were also well separated, with PC1 explaining $63.48 \%$ of the variation and PC2 explaining $10.12 \%$ of the variance (Figure 3b). Overall, the two components clearly separated the AOB and AOA 
community compositions according to the differences in management practices, including $\mathrm{N}$ fertilization and biochar addition.
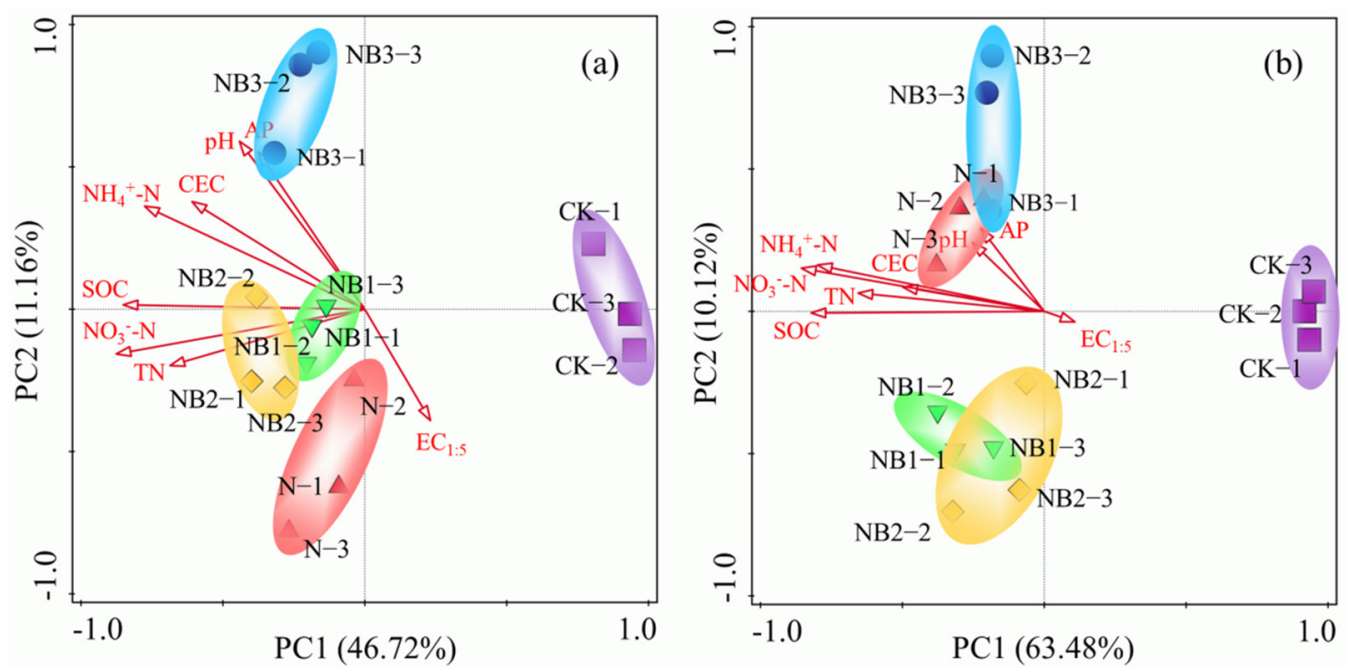

Figure 3. Principal coordinate analysis of AOA (a) and AOB (b) communities in soils with different salinities.

The relationships between environmental variables and the community compositions of $\mathrm{AOB}$ and AOA were determined using redundancy analysis (RDA). Figure 4 shows the environment-species relevance based upon the relative abundance data matrix of dominant taxa at the genus level. Apparently, soil SOC, $\mathrm{NO}_{3}{ }^{-}-\mathrm{N}$ and $\mathrm{pH}$ were the significant environmental factors shaping the AOB community structure. The contribution of the environmental variable to the total explanatory variance is followed by the solely explanatory variance by this variable: SOC-61.8\% (53.1\%), $\mathrm{pH}-14.3 \%(12.3 \%)$, and $\mathrm{NO}_{3}{ }^{-}-\mathrm{N}-11.0 \%$ $(9.4 \%)$. The first axis explained $69.90 \%$ of the variation $(p<0.01)$ and was correlated with soil $\mathrm{NO}_{3}{ }^{-}-\mathrm{N}$ and $\mathrm{SOC}$, indicating that the first axis may characterize soil nutrient status. The second axis explained $4.52 \%$ of the variation $(p<0.05)$ and was correlated with soil $\mathrm{pH}$, representing the status of the soil alkalinity. The differences in soil SOC, $\mathrm{NO}_{3}{ }^{-}-\mathrm{N}$ and $\mathrm{pH}$, as induced by $\mathrm{N}$ fertilization and biochar addition, contributed to the structural variation of the AOB community. For AOA, the community structure was mainly dominated by SOC and $\mathrm{pH}$, and the explanatory contribution and variance related to the environmental variables were SOC-67.5\% (54.3\%) and $\mathrm{pH}-10.6 \%$ (8.5\%). The first axis explained $54.86 \%$ of the variation $(p<0.01)$ and characterized the soil nutrient status. The second axis represented the soil alkalinity status and explained $7.94 \%$ of the variation $(p<0.01)$. The structural variation of the AOA community could be mainly ascribed to the difference in soil SOC and $\mathrm{pH}$.

\subsection{Linking Basic Soil Properties, Dominant Taxa and amoA Gene Copies to NR Using SEM}

The dependence between the relative abundance of dominant genera of AOB and AOA and nitrification rates, amo $A$ gene copies and basic soil properties, as expressed by Spearman's rank correlation coefficients, is given in Table 5. The NR exhibited a significantly positive correlation with the relative abundance of genera Nitrosospira and Norank_c_environmental_samples_p_Crenarchaeota, but a negative correlation with that of genera Nitrosovibrio,Unclassified_k_norank_d_Bacteria,Norank_p_ammonia_oxidizing_bacteria_ensemble, and Unclassified_k_norank_d_Archaea. Likewise, the numbers of both amoA-AOB and amoAAOA gene copies showed significantly positive responses to the relative abundance of genera Nitrosospira and Norank_c_environmental_samples_p_Crenarchaeota, but negative responses to that of genera Nitrosomonas, Unclassified_o_Nitrosomonadales, Nitrosovibrio, Unclassified_k_norank_d_Bacteria, Nitrososphaera, and Unclassified_k_norank_d_Archaea. Interestingly, the relative abundance of genera Nitrosospira and Norank_c_environmental_samples_p 
_Crenarchaeota showed negative correlation with most basic soil properties, but that of genera Unclassified_k_norank_d_Bacteria and Unclassified_k_norank_d_Archaea showed positive correlation with most basic soil properties.
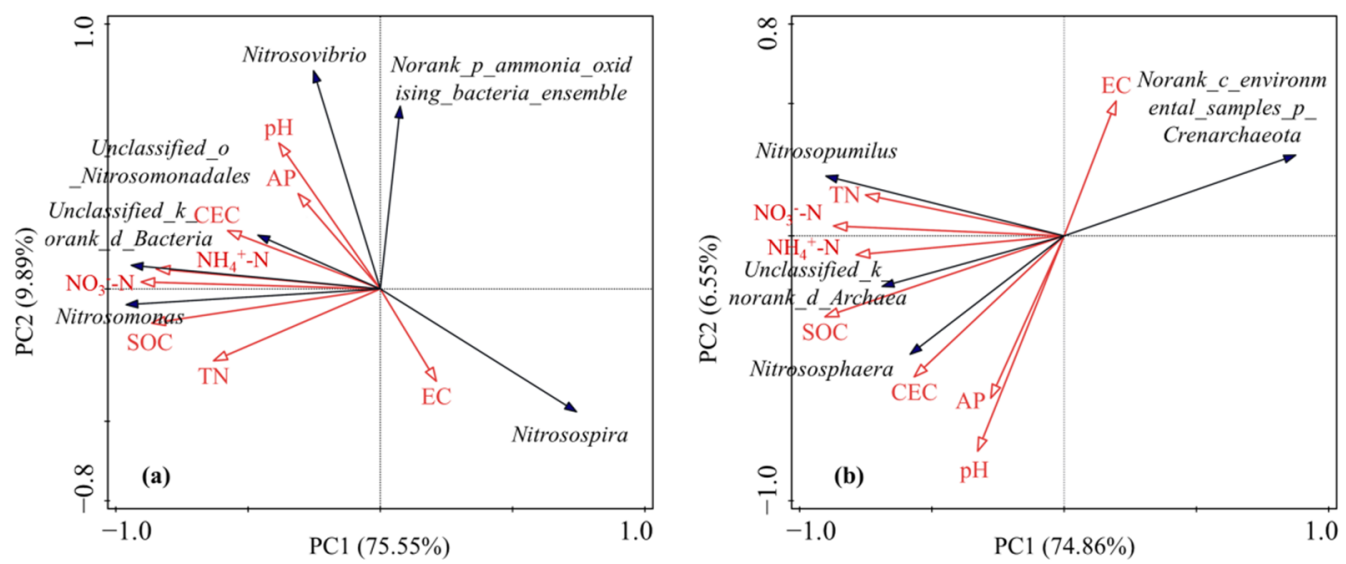

Figure 4. Redundancy analysis (RDA) diagram of the relationship between AOB (a) and AOA (b) community compositions (relative abundance of genus) and environmental factors.

Table 5. Spearman's rank correlations between the relative abundances of dominant genera of $\mathrm{AOB}$ and $\mathrm{AOA}$, and nitrification rate, gene copies of $a m o A-\mathrm{AOB}$ and $a m o A-\mathrm{AOA}$, and the soil basic properties $(n=15)$.

\begin{tabular}{|c|c|c|c|c|c|c|c|c|c|c|c|c|}
\hline & Genus & NR & $\begin{array}{l}\text { amoA- } \\
\text { AOB }\end{array}$ & $\begin{array}{l}\text { amoA- } \\
\text { AOA }\end{array}$ & $\mathrm{EC}_{1: 5}$ & $\mathrm{pH}$ & CEC & SOC & TN & $\begin{array}{c}\mathrm{NH}_{4}{ }^{+}- \\
\mathbf{N}\end{array}$ & $\begin{array}{c}\mathrm{NO}_{3}{ }^{-}- \\
\mathbf{N}\end{array}$ & AP \\
\hline \multirow{6}{*}{$\mathrm{AOB}$} & Nitrosospira & $0.622 *$ & $\underset{* *}{0.944}$ & $\underset{* *}{0.938}$ & 0.387 & $\underset{*}{-0.620}$ & $\underset{* *}{-0.737}$ & $-\underset{* *}{-0.859}$ & -0.489 & $-\underset{* *}{0.784}$ & $\underset{* *}{-0.712}$ & $\underset{*}{-0.534}$ \\
\hline & Nitrosomonas & -0.250 & $\underset{* *}{-0.67}$ & $\begin{array}{c}-0.564 \\
*\end{array}$ & -0.196 & 0.188 & 0.201 & 0.562 * & $0.505 *$ & $\begin{array}{c}0.759 \\
* *\end{array}$ & $\underset{* *}{0.781}$ & 0.075 \\
\hline & Unclassified_o_Nitrosomonadales & -0.301 & $\underset{*}{-0.564}$ & $-\underset{* *}{0.657}$ & -0.101 & 0.390 & $\underset{* *}{0.695}$ & $\underset{* *}{0.662}$ & 0.366 & 0.341 & 0.385 & 0.488 \\
\hline & Nitrosovibrio & $\underset{* *}{-0.640}$ & $\underset{*}{-0.505}$ & $\underset{* *}{-0.623}$ & -0.398 & $0.575^{*}$ & $\underset{* *}{0.736}$ & 0.394 & -0.149 & $0.504 *$ & 0.059 & $\underset{* *}{0.682}$ \\
\hline & Unclassified_k_norank_d_Bacteria & $\underset{* *}{-0.635}$ & $\underset{* *}{-0.864}$ & $\underset{* *}{-0.864}$ & -0.333 & $\underset{* *}{0.641}$ & $\underset{* *}{0.700}$ & $\begin{array}{c}0.779 \\
* *\end{array}$ & 0.395 & $\underset{* *}{0.672}$ & $0.607 *$ & $0.525^{*}$ \\
\hline & $\begin{array}{c}\text { Norank_p_ammonia_oxidising_bacteria } \\
\text { _ensemble }\end{array}$ & $\underset{*}{-0.549}$ & -0.379 & -0.437 & $\underset{*}{-0.565}$ & $0.572 *$ & $0.536 *$ & 0.285 & -0.030 & 0.156 & -0.106 & $0.507 *$ \\
\hline \multirow{4}{*}{ AOA } & Nitrososphaera & -0.387 & $\underset{*}{-0.599}$ & $\underset{*}{-0.592}$ & -0.287 & $0.515^{*}$ & 0.464 & $\underset{* *}{0.631}$ & 0.193 & $0.538 *$ & $0.558 *$ & 0.395 \\
\hline & Nitrosopumilus & 0.048 & -0.434 & -0.283 & 0.171 & -0.156 & 0.014 & 0.368 & $\underset{* *}{0.684}$ & 0.415 & $0.598 *$ & -0.162 \\
\hline & $\begin{array}{c}\text { Norank_c_environmental_samples } \\
\text { p_Crenarchaeota }\end{array}$ & $0.502 *$ & $\underset{* *}{0.936}$ & $\underset{* *}{0.851}$ & 0.225 & -0.429 & $\underset{*}{-0.581}$ & $-\underset{* *}{0.853}$ & $-\underset{* *}{* * 647}$ & -0.792 & $\underset{* *}{-0.864}$ & -0.339 \\
\hline & Unclassified_k_norank_d_Archaea & -0.687 & -0.749 & $\underset{* *}{-0.785}$ & -0.411 & $0.581 *$ & $\underset{* *}{0.728}$ & $0.612 *$ & 0.233 & $0.518^{*}$ & 0.394 & $0.532 *$ \\
\hline
\end{tabular}

* indicates significance at $p \leq 0.05 ;{ }^{* *}$ indicates significance at $p \leq 0.01$.

Figure 5 presents the relationships among the soil properties, the dominant genera of ammonia-oxidizing microorganisms, abundance of amo $A$ gene, and nitrification rates using structural equation models (SEMs). The causality among the above attributes was accurately captured by the SEM from the criteria of model performance, i.e., $\chi^{2} / d f$ of $0.972, p$ of 0.478 , GFI of 0.908 , and RMSEA close to 0 . SOC showed positive direct influences on the relative abundance of the genera Nitrosovibrio $(p<0.05)$ and $\mathrm{NO}_{3}{ }^{-}-\mathrm{N}(p<0.001)$, but negative direct influences on the relative abundance of Norank_c_environmental_samples_p_Crenarchaeota $(p<0.01)$ and number of amoA-AOA gene copies $(p<0.01)$. Soil $\mathrm{NO}_{3}{ }^{-}-\mathrm{N}$ content had a positive direct influence on the relative abundance of Nitrosomonas $(p<0.001)$, and a negative direct influence on that of Norank_c_environmental_samples_p_Crenarchaeota $(p<0.001)$. Additionally, the numbers of $a m o A-A O B$ and $a m o A-A O A$ gene copies were positively altered by the relative abundance of Nitrosomonas $(p<0.05)$ and Norank_c_environmental_samples_p_ Crenarchaeota $(p<0.001)$, but negatively altered by the relative abundance of Nitrosovib- 
rio $(p<0.001)$. In addition to the direct influence, SOC had an indirect influence on NR through the numbers of $a m o A-\mathrm{AOB}$ and $a m o A-\mathrm{AOA}$ gene copies, which were directly responsive to the relative abundance of Nitrosovibrio $(p<0.001)$. Soil $\mathrm{NO}_{3}{ }^{-}-\mathrm{N}$ content also had an indirect positive influence on NR through the numbers of $a m o A-\mathrm{AOB}$ and amoA-AOA gene copies, which were directly influenced by Nitrosomonas $(p<0.05)$. It was interesting to find that a common pathway through the relative abundance of $\mathrm{No}^{-}$ rank_c_environmental_samples_p_Crenarchaeota existed for $\mathrm{SOC}$ and $\mathrm{NO}_{3}{ }^{-}-\mathrm{N}$ content. That was, both $\mathrm{SOC}$ and $\mathrm{NO}_{3}{ }^{-}-\mathrm{N}$ content had indirect influence on $\mathrm{NR}$ through the relative abundance of Norank_c_environmental_samples_p_Crenarchaeota, and numbers of amoA-AOB and amoA-AOA gene copies. A total of $86.3 \%$ of the variation in NR was explained by the SEM model, and the proportions of the explainable variation in the relative abundance of Nitrosomonas, Nitrosovibrio, Nitrososphaera, and Norank_c_environmental_samples_p_Crenarchaeota, and numbers of $a m o A-\mathrm{AOB}$ and $a m o A-\mathrm{AOA}$ gene copies were $61.1 \%, 27.5 \%, 41.6 \%, 84.6 \%$, $96.2 \%$ and $96.1 \%$, respectively.

$\chi^{2} / \mathrm{df}=0.972, p=0.478, \mathrm{GFI}=0.908, \mathrm{RMSEA}=0.002$

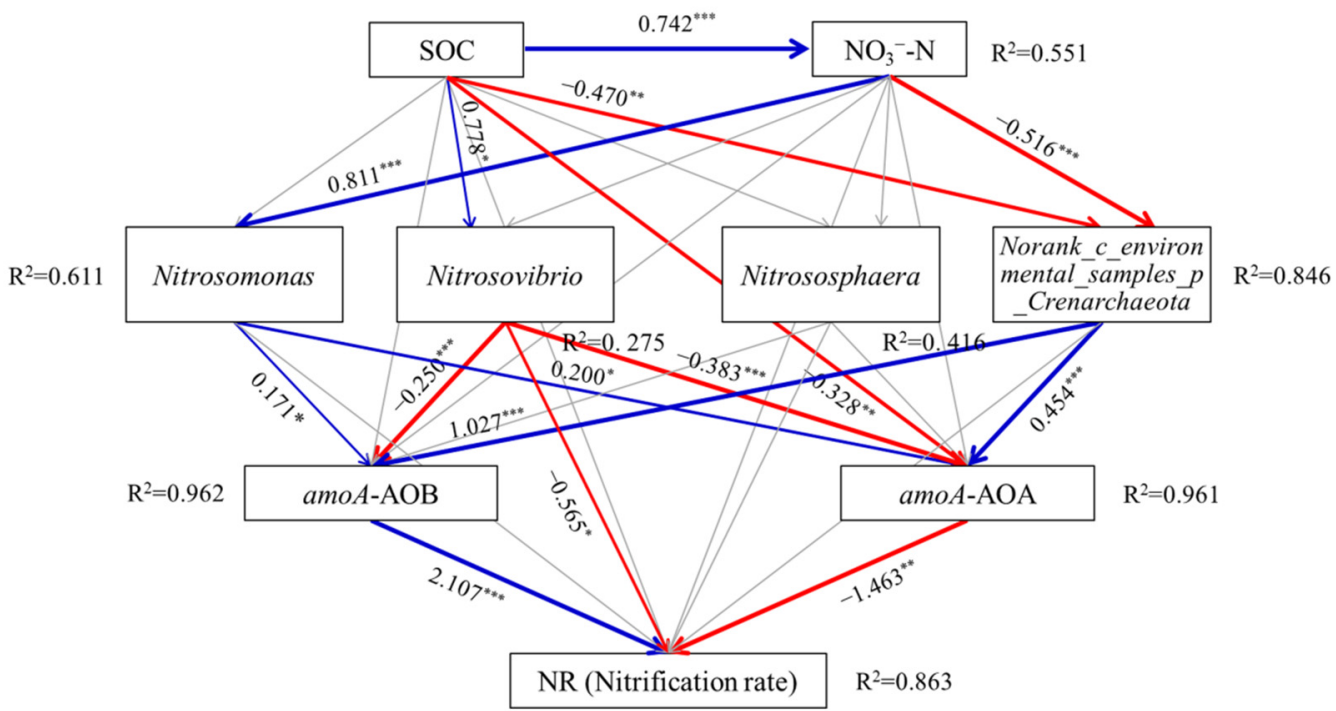

Figure 5. Structural equation models showing the effects of soil properties ( $\mathrm{SOC}$ and $\mathrm{NO}_{3}{ }^{-}-\mathrm{N}$ ) induced by biochar addition, dominant taxa of ammonia-oxidizing microorganisms, and $a m o \mathrm{~A}$ gene abundance on the soil nitrification rate (NR) at the genus level. Blue and red arrow lines indicate significant positive and negative relationships, respectively. Gray arrow lines indicate nonsignificant relationships. Numbers above arrow lines are standardized path coefficients. $R^{2}$ indicates the proportion of variance explained by the model. ${ }^{* *} p<0.001$; ${ }^{* *} p<0.01$; $^{*} p<0.05$.

\section{Discussion}

4.1. Responses of Soil Properties, Nitrification Ability, and amoA Gene Copies to Biochar Addition in Salt-Affected Soil

Biochar has been extensively used as an effective amendment for soil salinization hazards because it enhances the nutrient supply capacity, modulates porosity and pore size, improves hydraulic parameters, and promotes soil aggregate structure [32]. Usman et al. found that the inhibitory effect of soil salinization on vegetative growth tended to decline owing to the increases in soil organic matter and nutrient availability induced by the application of biochar, especially at high application rates [33]. This was in line with our study showing that biochar addition improved soil $\mathrm{pH}, \mathrm{CEC}, \mathrm{SOC}, \mathrm{NH}_{4}{ }^{+}-\mathrm{N}$ and AP (Table 1). Zhu et al. discovered that biochar addition as a buried layer in the soil profile caused a breakdown in the continuity of capillary movement and accelerated the leaching rate of soluble salts because of the large pore volume and pore size of biochar [34]. However, this was not found in the present study, and the soil salinity was not different among treatments. The explanation was that excessive flooding irrigation, which exceeded the 
water requirements of crops and salt leaching, are commonly used in the Hetao Irrigation District. Moreover, biochar addition was found to improve nutrient supply capacity in saline soil owing to its high specific surface area and saturation moisture content. Yang et al. reported that the leaching loss of soil $\mathrm{NO}_{3}{ }^{-}-\mathrm{N}$ was reduced at any biochar application rate, and a high biochar application rate reduced soil $\mathrm{NH}_{4}{ }^{+}-\mathrm{N}$ leaching, but soil $\mathrm{NH}_{4}{ }^{+}-\mathrm{N}$ leaching significantly increased at a low biochar application rate $(<1 \mathrm{wt} \%)$ [35]. This was also observed in non-saline and acidic soils $[36,37]$, and coincided with the findings of this study.

Soil nitrification rate was closely associated with the abundance of amo $A$ gene, and AOB-dominated nitrification and $a m o A-A O B$ gene abundance were predominant in alkaline soil, whereas AOA-dominated nitrification and amoA-AOA gene abundance were dominant in acidic soil [38]. Data on the influence of biochar addition on nitrification and amo $A$ gene abundance in saline soils are currently inconsistent for different soil textures, salinization types, and nutrient statuses, i.e., promotion [17,39], inhibition [40,41], or indifference [42]. The possible stimulating pathways of biochar addition on nitrification in salt-affected soil include: (1) the improvement of biological activity of functional microorganisms associated with nitrification [11]; (2) the provision of favorable microhabitats for the growth of ammonia-oxidizing microorganisms by biochar owing to its high cation exchange capacity (CEC), hydrophilicity, and adsorption capacity [43]; and (3) the promotion of nitrogen mineralization and $\mathrm{NH}_{4}{ }^{+}-\mathrm{N}$ concentration, which acts as a substrate for nitrification [44]. In contrast, there are still many factors contributing to nitrification inhibition under biochar addition: (1) the increase of soil $\mathrm{pH}$ and ammonia volatilization, and the decline of the substrate content for nitrification [45]; (2) the reduction of the bioavailability of $\mathrm{NH}_{4}{ }^{+}-\mathrm{N}$ through physical adsorption and pore filling [46]; and (3) the shift of the community structure of functional microorganisms due to the reactive functional groups and free radicals on the biochar surface [12]. In fact, the performance of biochar addition largely depends on the prevailing factors in the nitrification process.

\subsection{Biochar Addition Shifted the Community Structures of $A O B$ and AOA in Salt-Affected Soil}

The rate-limiting step of nitrification, i.e., ammonia oxidation, is controlled by both $\mathrm{AOB}$ and $\mathrm{AOA}$, but the contributions of $\mathrm{AOB}$ and $\mathrm{AOA}$ to nitrification vary depending on environmental conditions [47]. Most reports show that biochar addition has a significant influence on the richness, diversity and community structures of AOB and AOA, but the conclusions are inconsistent for different soil alkalinities, parent materials, and salinization types [6]. This was also the case under biochar application conditions. Zhang et al. reported that straw biochar application significantly shifted the AOB community composition, and the abundance of amoA-AOB gene contributed to soil potential nitrification rates (PNR), whereas the abundance of amoA-AOA gene was almost not responsive to biochar addition [10]. Similarly, $\mathrm{Xu}$ et al. discovered that a significant response in amoA-AOB gene abundance, rather than $a m o A-A O A$ gene abundance, was observed under biochar application, although biochar addition significantly increased the diversity indices of $\mathrm{AOB}$ and AOA [48]. In a recent study, $\mathrm{Li}$ et al. concluded that biochar stimulated amoA-AOB gene abundance, which was significantly more abundant than amoA-AOA gene abundance, but the amoA activity showed a significant negative correlation with soil salinity and watersoluble carbon [49]. Most of the above findings were in accord with the present study in that $\mathrm{AOB}$ made a larger contribution to the nitrification rate and were more abundant than AOA. However, the present study showed that biochar suppressed amoA-AOB and amoA-AOA gene abundance. The explanation was that biochar addition decreased the frequency of functional microorganisms by increasing the diversity of $\mathrm{AOB}$ and $\mathrm{AOA}$, and increased soil $\mathrm{pH}$ (Table 1), which exceeded the optimum value for amo $A$ growth and activity [50].

The community structures of $\mathrm{AOB}$ and $\mathrm{AOA}$ showed distinct responses to biochar addition, with AOB being more susceptible than AOA to biochar. Most of the previous reports linked the functional changes with the abundance of comammox Nitrospira. Lin et al. 
reported that biochar addition increased the soil $\mathrm{pH}$, diversity and abundance of amoA gene, and shifted the AOB community structure from Nitrosospira-dominated to Nitrosomonasdominated [19]. Shi et al. discovered that Nitrosospira was the dominant genus in saline-alkali soil with a high $\mathrm{NO}_{3}{ }^{-}-\mathrm{N}$ content and salinity level, and biochar addition decreased the relative abundance of Nitrosomonas but increased that of Nitrosovibrio [16]. These findings were consistent with the present study, which confirmed that biochar addition decreased the relative abundance of Nitrosospira and Nitrosomonas but increased that of Nitrosovibrio. Li et al. reported that the reduced nitrification under biochar addition was mainly ascribed to the decrease in the abundance of comammox Nitrospira, which played a pivotal role in driving soil nitrification [51]. Bi et al. found that biochar addition shifted the community composition of AOB rather than AOA, with Nitrosospira Cluster 3a and Cluster 0 as the single predominant group of AOB [52]. More recently, Zhao et al. concluded that salinity gradients shaped the community composition and ecophysiology of comammox Nitrospira, which showed a clear response to a wide range of salinity levels [53]. This was consistent with [17] that the AOB community structure was more responsive to soil salinity dynamics induced by biochar application, and the biochar application rate affected the community composition of $\mathrm{AOB}$ and nitrification.

\subsection{Causality among Soil Environmental Traits, Community Structures, amoA Gene Copies and Nitrification Rate under Biochar Addition}

Genera Nitrosospira, Nitrosomonas, Nitrososphaera and Nitrosopumilus were dominant in community structure of ammonia-oxidizing microorganisms in the salt-affected irrigationsilting soil. This was in line with [54] that in a salt-affected alluvial delta area, the genus Nitrosopumilus dominated ammonia oxidization in vegetable soil and Nitrosospira dominated ammonia oxidization in wheat-maize rotation soil, whereas the dominant taxon was Nitrosomonas in paddy soil. The NR and numbers of amoA-AOB and amoA-AOA gene copies had significantly positive correlation with the relative abundance of Nitrosospira, and a negative correlation with the relative abundance of Nitrosovibrio. The relative abundance of genera Nitrosomonas and Nitrososphaera was negatively correlated with the numbers of amoA-AOB and $a m o A-A O A$ gene copies. These findings were consistent with Zhang et al., who reported that $\mathrm{AOB}$ rather than $\mathrm{AOA}$ dominated nitrification activity and that Nitrosospira Cluster 3-like AOB predominantly catalyzed bacterial ammonia oxidation [55]. In contrast, $\mathrm{Xu}$ et al. discovered that the genus Nitrososphaera played a critical role in the soil autotrophic nitrification activity of acidic upland soils, whereas nitrification activity was negatively correlated with the relative abundance of Nitrosospira [36]. This result was not unexpected as AOB dominated autotrophic nitrification in alkaline soil, but AOA were dominant in acidic soil. Recently, Hou et al. found that under biochar addition, the genus Nitrosomonas was the most abundant bacteria in microaggregates and positively correlated with the nitrification rate in acidic paddy soil [56]. This was also found by [57] in a saline aquaculture biofilm.

Nitrification, as a microbe-mediated process, was functionally associated with the abundance and community structures of $\mathrm{AOB}$ and $\mathrm{AOA}$, which was more likely to result from the shifts in soil environmental traits induced by biochar addition [56]. In the present study, SEM captured the causal relationships among the soil properties, relative abundance of dominant taxa of $\mathrm{AOB}$ and $\mathrm{AOA}$, and abundance of amoA gene on the nitrification rate. SOC and $\mathrm{NO}_{3}{ }^{-}-\mathrm{N}$ explained most of the structural variation in the $\mathrm{AOB}$ and $\mathrm{AOA}$ communities. Both $\mathrm{SOC}$ and soil initial $\mathrm{NO}_{3}{ }^{-}-\mathrm{N}$ content exhibited negative and positive indirect influences on NR. Evidence from [58] confirmed that the small-scale variation in ammonia oxidizers within saline sediments was dominated by Nitrosomonas and amoA-AOB abundance. It was also reported that combined biochar and urea amendment improved the relative abundance of Nitrosomonas, which dominated over Nitrosospira and nitrite-oxidizing bacteria (NOB) communities [59]. Moreover, the abundance of AOA showed a negative correlation with nitrification potential for the soil with a C:N ratio greater than 10 [60]. This partially explained the negative influence of amoA-AOA gene abundance on NR. In the 
present study, the potential mechanism of nitrification inhibition is that biochar addition improved the alpha diversity of AOB and AOA communities, shifted the community structure and decreased the relative abundance of dominant ammonia-oxidizers. This could be witnessed from the correlation among NR, amo $A$ gene copies and Shannon index for AOB and AOA (Supplementary Figure S2). Moreover, soil microhabitat traits including high $\mathrm{pH}, \mathrm{C}: \mathrm{N}$ ratio, organic matter, soil salinity also contributed to nitrification inhibition. Hou et al. pointed out that the initial soil fertility status, which was closely related to basal nitrification, should be fully considered when using biochar to mediate nitrification [56].

\section{Conclusions}

Under $\mathrm{N}$ fertilization conditions, biochar addition inhibited the average nitrification rate and numbers of $a m o A-\mathrm{AOB}$ and $a m o A-\mathrm{AOA}$ gene copies in moderately salinized irrigation-silting soil, and the inhibitory effect increased with the biochar application rate. Biochar addition decreased the OTUs of both AOB and AOA, increased the alpha diversity of AOB but decreased that of AOA. Biochar addition and $\mathrm{N}$ fertilization shifted the AOB community structure from Nitrosospira-dominated to Nitrosospira and Nitrosomonas-dominated and changed the AOA community from Nitrososphaera-dominated to Nitrososphaera and Nitrosopumilus-dominated. For the AOB community, biochar addition decreased the relative abundance of Nitrosospira and Nitrosomonas, but increased that of Nitrosovibrio, Unclassified_k_norank_d_Bacteria and Norank_p_ammonia_oxidising_bacteria _ensemble under $\mathrm{N}$ fertilization. For the AOA community, biochar addition enhanced the relative abundance of Nitrososphaera, but decreased that of Nitrosopumilus under $\mathrm{N}$ fertilization. Soil microhabitat traits including SOC, $\mathrm{pH}$ and $\mathrm{NO}_{3}{ }^{-}-\mathrm{N}$ explained $87.1 \%$ of the total variation in the AOB community, and a total of $78.1 \%$ variation in the AOA community was explanatory by soil $\mathrm{pH}$ and SOC. Results of structural equation models (SEMs) showed that SOC had indirect influence on NR through Nitrosovibrio, Norank_c _environmental_samples_p_Crenarchaeota and amoA-AOB and amoA-AOA gene abundance, and $\mathrm{NO}_{3}{ }^{-}-\mathrm{N}$ had indirect influence on NR through Nitrosomonas, Norank_c_environmental _samples_p_Crenarchaeota and amoA-AOB and amoA-AOA gene abundance. Our conclusion is that biochar addition inhibits nitrification by improving the community diversity of $\mathrm{AOB}$, shifting the community structures of $\mathrm{AOB}$ and $\mathrm{AOA}$, and reducing the relative abundance of dominant functional ammonia-oxidizers. Soil microhabitat traits and unclassified ammonia-oxidizing microorganism also play an important role in nitrification inhibition, which still needs further efforts to validate using long-term observation experiments.

Supplementary Materials: The following supporting information can be downloaded at: https: / / www.mdpi.com/article/10.3390/microorganisms10020436/s1, Figure S1: Temporal dynamics of nitrification rate at different times across the incubation period, plus one-way analysis of variance (ANOVA) with the least significant difference (LSD). ${ }^{* *}$ indicates significance at $p \leq 0.01$; Figure S2: Relationships among nitrification rate, amoA gene copies and Shannon index for AOB and AOA communities; Table S1: The amplification primer, sequence and reaction condition of quantitative PCR for $a m o A$-AOB and $a m o A$-AOA genes.

Author Contributions: Conceptualization, R.-J.Y. and J.-S.Y.; methodology, R.-J.Y.; formal analysis, H.-Q.L.; investigation, X.-P.W., W.-P.X. and X.Z.; writing-original draft preparation, R.-J.Y. and H.-Q.L.; writing-review and editing, R.-J.Y.; supervision, J.-S.Y. All authors have read and agreed to the published version of the manuscript.

Funding: The research is supported by the National Natural Science Foundation of China (No. U1806215; No. U1906221; No. 42077084), the National Key Research \& Development Program of China (No. 2019YFD1002702; No. 2019YFD0900702), and the Major Science \& Technology Projects of Inner Mongolia Autonomous Region (No. NMKJXM202009).

Institutional Review Board Statement: Not applicable.

Informed Consent Statement: Not applicable. 
Data Availability Statement: The data and results of this study are available upon reasonable request. Please contact the main author of this publication.

Acknowledgments: Fu-Le Zheng, Jian-Yu Tao, Hai Zhu, Chun-Yan Yin and Yu-Peng Jing are thanked for their help during field experiment and lab analysis. Anonymous reviewers are also thanked for their valuable comments on improving this manuscript.

Conflicts of Interest: The authors declare no conflict of interest. The funders had no role in the design of the study; in the collection, analyses, or interpretation of data; in the writing of the manuscript, or in the decision to publish the results.

\section{References}

1. Ghafoor, I.; Habib-Ur-Rahman, M.; Ali, M.; Afzal, M.; Ghaffar, A. Slow-release nitrogen fertilizers enhance growth, yield, NUE in wheat crop and reduce nitrogen losses under an arid environment. Environ. Sci. Pollut. Res. 2021, 28, 43528-43543. [CrossRef] [PubMed]

2. Libutti, A.; Monteleone, M. Soil vs. groundwater: The quality dilemma. Managing nitrogen leaching and salinity control under irrigated agriculture in Mediterranean conditions. Agrc. Water Manag. 2017, 186, 40-50. [CrossRef]

3. Zhou, M.H.; Butterbach-Bahl, K.; Vereecken, H.; Brüggemann, N. A meta-analysis of soil salinization effects on nitrogen pools, cycles and fluxes in coastal ecosystems. Glob. Chang. Biol. 2017, 23, 1338-1352. [CrossRef]

4. Liu, Z.Q.; He, T.Y.; Cao, T.; Yang, T.X.; Meng, J.; Chen, W.F. Effects of biochar application on nitrogen leaching, ammonia volatilization and nitrogen use efficiency in two distinct soils. J. Soil Sci. Plant Nutr. 2017, 17, 515-528. [CrossRef]

5. Mao, W.B.; Kang, S.Z.; Wan, Y.S.; Sun, Y.X.; Li, X.H.; Wang, Y.F. Yellow river sediment as a soil amendment for amelioration of saline land in the Yellow River Delta. Land Degrad. Dev. 2014, 27, 1595-1602. [CrossRef]

6. Zhang, H.M.; Xiong, Y.W.; Huang, G.H.; Xu, X.; Huang, Q.Z. Effects of water stress on processing tomatoes yield, quality and water use efficiency with plastic mulched drip irrigation in sandy soil of the Hetao Irrigation District. Agric. Water Manag. 2017, 179, 205-214. [CrossRef]

7. Lal, R. Organic Matter, Effects on Soil Physical Properties and Processes; Gliński, J., Horabik, J., Lipiec, J., Eds.; Encyclopedia of Agrophysics Encyclopedia of Earth Sciences Series Springer; Springer: Dordrecht, The Netherlands, 2011; pp. 528-534.

8. Sun, J.N.; Yang, R.Y.; Zhu, J.J.; Pan, Y.H.; Yang, M.; Zhang, Z.H. Can the increase of irrigation frequency improve the rate of water and salt migration in biochar-amended saline soil? J. Soil. Sediment. 2019, 19, 4021-4030. [CrossRef]

9. Munir, A.; Shehzad, M.T.; Qadir, A.A.; Murtaza, G.; Khalid, H.I. Use of potassium fertilization to ameliorate the adverse effects of saline-sodic stress condition $\left(\mathrm{EC}_{\mathrm{W}}\right.$ : SAR $\mathrm{w}$ levels) in rice (Oryza Sativa L.). Commun. Soil Sci. Plan. Anal. 2019, 50, $1975-1985$. [CrossRef]

10. Zhang, Q.; Liu, B.J.; Yu, L.; Wang, R.R.; Zheng, H.; Luo, X.X.; Li, F.M. Effects of biochar amendment on carbon and nitrogen cycling in coastal saline soils: A review. J. Nat. Res. 2019, 34, 2529-2543.

11. Shi, Y.L.; Liu, X.R.; Gao, P.L.; Zhang, Q.W.; Yang, Z.L. Effects of biochar and organic fertilizer on saline-alkali soil $\mathrm{N}_{2} \mathrm{O}$ emission in the North China Plain. Environ. Sci. 2017, 38, 5333-5343.

12. Wang, Z.Y.; Zong, H.Y.; Zheng, H.; Liu, G.C.; Chen, L.; Xing, B.S. Reduced nitrification and abundance of ammonia-oxidizing bacteria in acidic soil amended with biochar. Chemosphere 2015, 138, 576-583. [CrossRef] [PubMed]

13. Li, F.; Liang, X.; He, S.; Li, M.; Cao, Y.; Zhang, J.; Tian, G. Biochar slows gross nitrification and gasses $\mathrm{N}$ emission via lower autotrophic nitrification in paddy soils. J. Soils Sediments 2020, 2, 629-640. [CrossRef]

14. Zhu, X.; Burger, M.; Doane, T.A.; Horwath, W.R. Ammonia oxidation pathways and nitrifier denitrification are significant sources of $\mathrm{N}_{2} \mathrm{O}$ and $\mathrm{NO}$ under low oxygen availability. Proc. Natl. Acad. Sci. USA 2013, 110, 6328-6333. [CrossRef] [PubMed]

15. Meinhardt, K.A.; Stopnisek, N.; Pannu, M.W.; Strand, S.E.; Fransen, S.C.; Casciotti, K.L.; Stahl, D.A. Ammonia-oxidizing bacteria are the primary $\mathrm{N}_{2} \mathrm{O}$ producers in an ammonia-oxidizing archaea dominated alkaline agricultural soil. Environ. Microbiol. 2018, 20, 2195-2206. [CrossRef]

16. Shi, Y.L.; Liu, X.R.; Zhang, Q.W.; Gao, P.L.; Ren, J.Q. Biochar and organic fertilizer changed the ammonia-oxidizing bacteria and archaea community structure of saline-alkali soil in the North China Plain. J. Soils Sediments 2020, 20, 12-23. [CrossRef]

17. Song, Y.; Zhang, X.; Ma, B.; Chang, S.X.; Gong, J. Biochar addition affected the dynamics of ammonia oxidizers and nitrification in microcosms of a coastal alkaline soil. Biol. Fertil. Soils 2014, 50, 321-332. [CrossRef]

18. Liu, Z.; Shang, H.; Han, F.; Zhang, M.; Zhou, W. Improvement of nitrogen and phosphorus availability by Pseudoalteromonas sp. during salt-washing in saline-alkali soil. Appl. Soil Ecol. 2021, 6, 104117. [CrossRef]

19. Lin, Y.; Ding, W.; Liu, D.; He, T.; Yoo, G.; Yuan, J.; Chen, Z.; Fan, J. Wheat straw-derived biochar amendment stimulated $\mathrm{N}_{2} \mathrm{O}$ emissions from rice paddy soils by regulating the amoA genes of ammonia-oxidizing bacteria. Soil Biol. Biochem. 2017, 113, 89-98. [CrossRef]

20. Shi, Y.L.; Liu, X.R.; Zhang, Q.W. Effects of combined biochar and organic fertilizer on nitrous oxide fluxes and the related nitrifier and denitrifier communities in a saline-alkali soil. Sci. Total Environ. 2019, 686, 199-211. [CrossRef]

21. Ren, D.Y.; Xu, X.; Hao, Y.; Huang, G.H. Modeling and assessing field irrigation water use in a canal system of Hetao, upper Yellow River basin: Application to maize, sunflower and watermelon. J. Hydrol. 2016, 532, 122-139. [CrossRef] 
22. Yao, R.J.; Li, H.Q.; Yang, J.S.; Zhu, W.; Yin, C.Y.; Wang, X.P.; Xie, W.P.; Zhang, X. Combined application of biochar and N fertilizer shifted nitrification rate and $a m o A$ gene abundance of ammonia-oxidizing microorganisms in salt-affected anthropogenic-alluvial soil. Appl. Soil Ecol. 2022, 171, 104348. [CrossRef]

23. Yao, R.J.; Li, H.Q.; Yang, J.S.; Yin, C.Y.; Wang, X.P.; Xie, W.P.; Zhang, X. Interactive effects of amendment materials and soil salinity on net rates of urea hydrolysis and nitrification in salt-affected soil. J. Soil Sci. Plant Nutr. 2021, 21, 3414-3427. [CrossRef]

24. Lu, R. Methods of Soil and Agro-chemical Analysis; China Agricultural Science and Technology Press: Beijing, China, 2000; pp. 127-332.

25. Brodie, E.L.; Edwards, S.; Clipson, N. Soil fungal community structure in a temperate upland grassland soil. FEMS Microbiol. Ecol. 2003, 45, 105-114. [CrossRef]

26. Limpiyakorn, T.; Sonthiphand, P.; Rongsayamanont, C.; Polprasert, C. Abundance of amoA genes of ammonia-oxidizing archaea and bacteria in activated sludge of full-scale wastewater treatment plants. Bioresour. Technol. 2011, 102, 3694-3701. [CrossRef]

27. Edgar, R.C. Search and clustering orders of magnitude faster than BLAST. Bioinformatics 2010, 26, 2460-2461. [CrossRef]

28. Caporaso, J.G.; Kuczynski, J.; Stombaugh, J.; Bittinger, K.; Bushman, F.D.; Costello, E.K.; Fierer, N.; Peña, A.G.; Goodrich, J.K.; Gordon, J.I.; et al. QIIME allows analysis of high-throughput community sequencing data. Nat. Methods 2010, 7, 335-336. [CrossRef]

29. Ye, C.; Cheng, X.L.; Liu, W.Z.; Zhang, Q.F. Revegetation impacts soil nitrogen dynamics in the water level fluctuation zone of the three gorges reservoir, China. Sci. Total Environ. 2015, 517, 76-85. [CrossRef]

30. Magurran, A.E. Open questions: Some unresolved issues in biodiversity. BMC Biol. 2013, 11, 118. [CrossRef]

31. Fan, Y.; Chen, J.Q.; Shirkey, G.; John, R.; Wu, S.R.; Park, H.; Shao, C.L. Applications of structural equation modeling (SEM) in ecological studies: An updated review. Ecol. Process. 2016, 5, 19. [CrossRef]

32. Cui, Q.; Xia, J.; Yang, H.; Liu, J.; Shao, P. Biochar and effective microorganisms promote sesbania cannabina growth and soil quality in the coastal saline-alkali soil of the Yellow River Delta, China. Sci. Total Environ. 2021, 756, 143801. [CrossRef]

33. Usman, A.; Al-Wabel, M.I.; Yong, S.O.; Al-Harbi, A.; Wahb-Allah, M.; El-Naggar, A.H.; Ahmad, M. Conocarpus biochar induces changes in soil nutrient availability and tomato growth under saline irrigation. Pedosphere 2016, 26, 27-38. [CrossRef]

34. Zhu, W.; Yang, J.S.; Yao, R.J.; Wang, X.P.; Xie, W.P.; Shi, Z.G. Buried layers change soil water flow and solute transport from the Yellow River Delta, China. J. Soil. Sediments 2021, 21, 1598-1608. [CrossRef]

35. Yang, F.; Li, X.Q.; Xing, Y.; Cheng, H.G.; Zhang, L.K.; He, Y.Y.; Wang, B. Effect of biochar amendment on nitrogen leaching in saline soil. J. Agro-Environ. Sci. 2014, 33, 972-977.

36. Xu, B.L.; Zhong, W.H.; Huang, Q.R.; Qin, H.Y.; Deng, H. Nitrification activity and autotrophic nitrifiers in long-term fertilized acidic upland soils. Environ. Sci. 2017, 8, 3473-3482.

37. Gunarathne, V.; Senadeera, A.; Vithanage, M. Effect of biochar and organic amendments on acid saline soil. In Proceedings of the 2nd International Conference on Bioresources, Energy, Environment, and Materials Technology, Hongcheon, Korea, 10-13 June 2018.

38. He, L.; Bi, Y.; Zhao, J.; Pittelkow, C.M.; Zhao, X.; Wang, S.; Xing, G. Population and community structure shifts of ammonia oxidizers after four-year successive biochar application to agricultural acidic and alkaline soils. Sci. Total Environ. 2018, 619, 1105-1115. [CrossRef] [PubMed]

39. Prommer, J.; Wanek, W.; Hofhansl, F.; Trojan, D.; Offre, P.; Urich, T.; Schleper, C.; Sassmann, S.; Kitzler, B.; Soja, G. Biochar decelerates soil organic nitrogen cycling but stimulates soil nitrification in a temperate arable field trial. PLoS ONE 2014, 9, e86388. [CrossRef]

40. Sun, H.; Lu, H.; Chu, L.; Shao, H.; Shi, W. Biochar applied with appropriate rates can reduce N leaching, keep N retention and not increase $\mathrm{NH}_{3}$ volatilization in a coastal saline soil. Sci. Total Environ. 2017, 575, 820-825. [CrossRef]

41. Zhu, H.; Yang, J.S.; Yao, R.J.; Wang, X.P.; Xie, W.P.; Zhu, W.; Liu, X.Y.; Cao, Y.F.; Tao, J.Y. Interactive effects of soil amendments (biochar and gypsum) and salinity on ammonia volatilization in coastal saline soil. Catena 2020, 190, 104527. [CrossRef]

42. Luo, X.X.; Chen, L.; Zheng, H.; Chang, J.J.; Wang, H.F.; Wang, Z.Y.; Xing, B.S. Biochar addition reduced net N mineralization of a coastal wetland soil in the Yellow River Delta, China. Geoderma 2016, 282, 120-128. [CrossRef]

43. Steinbeiss, S.; Gleixner, G.; Antonietti, M. Effect of biochar amendment on soil carbon balance and soil microbial activity. Soil Biol. Biochem. 2009, 41, 1301-1310. [CrossRef]

44. Chen, $\mathrm{C} . ; \mathrm{Xu}, \mathrm{X} . ; \mathrm{Bi}, \mathrm{Z} . ; \mathrm{Xiong}$, Z. Effects of biochar and organic manure on $\mathrm{N}_{2} \mathrm{O}$ emissions and the functional gene abundance of nitrification and denitrification microbes under intensive vegetable production. Acta Sci. Circumst. 2017, 37, 1912-1920.

45. Mandal, S.; Thangarajan, R.; Bolan, N.S.; Sarkar, B.; Khan, N.; Ok, Y.S.; Naidu, R. Biochar-induced concomitant decrease in ammonia volatilization and increase in nitrogen use efficiency by wheat. Chemosphere 2016, 142, 120-127. [CrossRef] [PubMed]

46. Taghizadeh-Toosi, A.; Clough, T.J.; Sherlock, R.R.; Condron, L.M. A wood based low-temperature biochar captures NH 3 -N generated from ruminant urine-N, retaining its bioavailability. Plant Soil 2012, 353, 73-84. [CrossRef]

47. Falkowski, P.G.; Fenchel, T.; Delong, E.F. The microbial engines that drive Earth's biogeochemical cycles. Science 2008, 320, 1034-1039. [CrossRef] [PubMed]

48. Xu, N.; Tan, G.C.; Wang, H.Y.; Gai, X.P. Effect of biochar additions to soil on nitrogen leaching, microbial biomass and bacterial community structure. Eur. J. Soil Biol. 2016, 74, 1-8. [CrossRef]

49. Li, M.Y.; Zhao, J.C.; Yang, X.; Zhou, Y.Y.; Zhang, L.H.; Yang, Y.; Luo, L.; Yan, Q.Y. Responses of ammonia-oxidizing microorganisms to biochar and compost amendments of heavy metals-polluted soil. J. Environ. Sci. 2021, 102, 263-272. [CrossRef] 
50. Agustiyani, D.; Imamuddin, H.; Faridah, E.N.; Oedjijono, O. Effect of pH and organic substrate on growth and activities of ammonia-oxidizing bacteria. Biodiversitas J. Biol. Divers 2004, 5, 43-47. [CrossRef]

51. Li, S.; Chen, D.W.; Wang, C.; Chen, D.; Wang, Q. Reduced nitrification by biochar and/or nitrification inhibitor is closely linked with the abundance of comammox Nitrospira in a highly acidic sugarcane soil. Biol. Fertil. Soils 2020, 56, 1219-1228. [CrossRef]

52. Bi, Q.F.; Chen, Q.H.; Yang, X.R.; Li, H.; Zheng, B.X.; Zhou, W.W.; Liu, X.X.; Dai, P.B.; Li, K.J.; Lin, X.Y. Effects of combined application of nitrogen fertilizer and biochar on the nitrification and ammonia oxidizers in an intensive vegetable soil. $A M B$ Express 2017, 7, 198. [CrossRef]

53. Zhao, M.Y.; Tang, X.F.; Sun, D.Y.; Hou, L.J.; Liu, M.; Zhao, Q.; Klümper, U.; Quan, Z.X.; Gu, J.D.; Han, P. Salinity gradients shape the nitrifier community composition in Nanliu River Estuary sediments and the ecophysiology of comammox Nitrospira inopinata. Sci. Total Environ. 2021, 795, 148768. [CrossRef]

54. Miao, Y.J. Study on soil bacteria and nitrogen-cycling functional microorganisms of different land use types in the Yellow River Delta. Master's Thesis, Shandong University, Jinan, China, 2019.

55. Zhang, Q.; Li, Y.; He, Y.; Liu, H.Y.; Dumont, M.G.; Brookes, P.C.; Xu, J.M. Nitrosospira cluster 3-like bacterial ammonia oxidizers and Nitrospira-like nitrite oxidizers dominate nitrification activity in acidic terrace paddy soils. Soil Biol. Biochem. 2019, 131, 229-237. [CrossRef]

56. Hou, Q.; Zuo, T.; Wang, J.; Huang, S.; Wang, X.J.; Yao, L.R.; Ni, W.Z. Responses of nitrification and bacterial community in three size aggregates of paddy soil to both of initial fertility and biochar addition. Appl. Soil Ecol. 2021, 166, 104004. [CrossRef]

57. Foesel, B.U.; Gieseke, A.; Schwermer, C.; Stief, P.; Koch, L.; Cytryn, E.; De La Torré, J.R.; Rijn, J.V.; Minz, D.; Drake, H.L.; et al. Nitrosomonas Nm143-like ammonia oxidizers and Nitrospira marina-like nitrite oxidizers dominate the nitrifier community in a marine aquaculture biofilm. FEMS Microbiol. Ecol. 2008, 63, 192-204. [CrossRef] [PubMed]

58. Duff, A.M.; Zhang, L.M.; Smith, C.J. Small-scale variation of ammonia oxidisers within intertidal sediments dominated by ammonia-oxidising bacteria Nitrosomonas sp. amoA genes and transcripts. Sci. Rep. 2017, 7, 13200. [CrossRef] [PubMed]

59. Yu, L.; Homyak, P.M.; Kang, X.X.; Brookes, P.C.; Ye, Y.K.; Lin, Y.N.; Muhammad, A.; Xu, J.M. Changes in abundance and composition of nitrifying communities in barley (Hordeum vulgare L.) rhizosphere and bulk soils over the growth period following combined biochar and urea amendment. Biol. Fert. Soils 2020, 56, 169-183. [CrossRef]

60. Gao, S.J.; Chang, D.N.; Zou, C.Q.; Cao, W.D.; Gao, J.S.; Huang, J.; Bai, J.S.; Zeng, N.H.; Rees, R.M.; Thorup-Kristensen, K. Archaea are the predominant and responsive ammonia oxidizing prokaryotes in a red paddy soil receiving green manures. Eur. J. Soil Biol. 2018, 88, 27-35. [CrossRef] 